\title{
The transtheoretical model as applied to dietary behaviour and outcomes
}

\author{
Leslie Spencer $^{1 *}$, Christopher Wharton ${ }^{2}$, Sheila Moyle ${ }^{1}$ and Troy Adams ${ }^{3}$ \\ ${ }^{1}$ Department of Health and Exercise Science, Rowan University, 201 Mullica Hill Road, Glassboro, NJ 08028, USA \\ ${ }^{2}$ Rudd Center for Food Policy and Obesity, Yale University, New Haven, CT, USA \\ ${ }^{3}$ Rocky Mountain University of Health Professions, Provo, UT, USA
}

\begin{abstract}
The transtheoretical model (TTM) is a behavioural theory that describes behaviour change as occurring in five stages, ranging from precontemplation to maintenance. The purpose of the present paper is to review and synthesise the literature published since 1999 on applications of the TTM to dietary behaviour so that the evidence for the use of assessment tools and interventions based on this model might be evaluated. Six databases were identified and searched using combinations of key words. Sixty-five original, peer-reviewed studies were identified and summarised in one of three tables using the following categories: population $(n 21)$, intervention ( $n$ 25) and validation ( $n$ 19). Internal validity ratings were given to each intervention, and the body of intervention studies as a whole was rated. The evidence for using stage-based interventions is rated as suggestive in the areas of fruit and vegetable consumption and dietary fat reduction. Valid and reliable staging algorithms are available for fruit and vegetable consumption and dietary fat intake, and are being developed for other dietary behaviours. Few assessment tools have been developed for other TTM constructs. Given the popularity of TTM-based assessments and interventions, more research is warranted to identify valid and reliable assessment tools and effective interventions. While the evidence supports the validity of the TTM to describe populations and to form interventions, evidence of the effectiveness of TTM-based interventions is not conclusive.
\end{abstract}

Transtheoretical model: Dietary behaviour: Nutrition behaviour: Weight management

Introduced in $1981^{1}$, the transtheoretical model (TTM) has become one of the most popular and enduring theories in the field of health promotion and health education. The central concept within the theory is that behaviour change is most likely to happen when individuals engage in the right activities, or processes of change, at the right time, or stage. According to the theory, individuals are most likely to experience success in changing behaviour when they engage in strategies that are appropriate to their stage of readiness to make the change. It has been applied to diverse health behaviours, including the cessation of addictions, participation in cancer screening, and the adoption of positive lifestyle behaviours ${ }^{2}$.

\section{Overview of the transtheoretical model}

Many published papers provide a detailed description of the TTM, therefore only a brief overview of the model is offered here. The TTM is comprised of the following constructs: stages of change, processes of change, decisional balance, self-efficacy, and temptation. Stage of change refers to the degree of readiness an individual exhibits toward adopting healthful dietary behaviours. A generalised version of the five stages has been identified and used to classify behaviour $^{3}$. The stages are: (1) precontemplation, in which an individual may or may not be aware that a behaviour change is warranted and has no intention of changing within the next 6 months; (2) contemplation, in which an individual is aware that a change is warranted and is intending to change within the next 6 months; (3) preparation, in which an individual is planning to change within the next 4 weeks; (4) action, which begins the day an individual makes the behaviour change and lasts until they have maintained the change for 6 months; (5) maintenance, which begins after an individual has successfully maintained a behaviour change for 6 months. For many behaviours to which the TTM has been applied, staging algorithms specific to the behaviour have been developed. Nutrition and dietary behaviours are no exception, and several versions of the staging algorithm have been identified in a recent literature review ${ }^{4}$.

\footnotetext{
Abbreviation: TTM, transtheoretical model.

* Corresponding author: Associate Professor Leslie Spencer, fax + 1856256 5613, email Spencer@ rowan.edu
} 
A second construct of the TTM is the processes of change ${ }^{5}$. The processes of change are ten strategies that individuals use to facilitate forward movement through the stages. The idea is that one must use the appropriate processes for each stage to be most effective in achieving maintenance of the new behaviour. According to the TTM, the five cognitive processes (dramatic relief, consciousness raising, self-re-evaluation, environmental re-evaluation, and social liberation) are most effective for those in precontemplation and contemplation. The five behavioural processes (helping relationships, self-liberation, counter-conditioning, stimulus control, and reinforcement management) are most effective for those in preparation, action or maintenance.

Decisional balance describes the balance of the pros and cons of changing a behaviour ${ }^{5}$. Based on the work of Janis \& $\mathrm{Mann}^{6}$, decisional balance assumes that an individual will identify both reasons for changing a behaviour and reasons for not changing. Behaviour change is influenced by the relative weight of the perceived pros $v$. cons of change. For most behaviours, the pros of changing outweigh the cons of changing as an individual moves from contemplation into preparation. For those in precontemplation, the cons of changing usually outweigh the pros.

Developed by Bandura ${ }^{7}$, self-efficacy has been adopted as a TTM construct ${ }^{8}$. Self-efficacy is defined as the confidence one has in performing a behaviour. In dietary behaviour research, it could be assessed by a series of questions designed to determine how confident an individual is that he or she could successfully perform a diet-related behaviour if he or she wanted to.

Temptation is a TTM construct ${ }^{9}$ that has been used in some, but not all, health behaviours to which the TTM has been applied. It is a measure of the degree to which an individual feels tempted to lapse from the new healthy behaviour. It has been applied to exercise and smoking behaviour ${ }^{10,11}$ and may be applicable to dietary behaviour, although published studies have not attempted to measure this.

\section{Previous literature review of the transtheoretical model as applied to dietary behaviour}

In 1999, Horwath ${ }^{4}$ conducted a literature review of the TTM as applied to dietary behaviour that included thirty-four studies. Twenty-five studies tested the validity of the TTM as applied to dietary behaviour, five used the TTM to describe the dietary behaviour of populations, three used TTM constructs to assess a dietary intervention and one assessed a TTM-based dietary intervention (i.e. stagematched intervention). Horwath ${ }^{4}$ made six significant observations at the conclusion of her review: (1) there were insufficient TTM-based interventions or prospective studies to determine whether these types of interventions are warranted; (2) most studies focused solely on the stage-ofchange construct and excluded the equally important construct of processes of change; (3) nutrient-based dietary intake was frequently misclassified by the staging algorithms used; (4) many studies focused on nutrientbased dietary intake rather than more easily measured foodbased eating behaviours; (5) there was no agreement as to how to measure stage for dietary behaviour; (6) the constructs decisional balance, processes of change, and selfefficacy appeared to be reliable in describing each stage of dietary behaviour.

\section{Purpose of the present literature review}

Since the publication of Horwath's literature review ${ }^{4}$, the body of nutrition-based TTM literature has more than doubled. A review of the more recent studies is warranted to determine if Horwath's original six conclusions still apply and if new evidence exists to support the application of the TTM to dietary behaviour. The present paper is fifth in a series of literature reviews of the TTM as applied to select health behaviours (including substance abuse, exercise, tobacco and cancer screening) using a systematic review process $^{10-13}$. The purpose of the present paper is to systematically review the studies of the TTM as applied to dietary behaviour that have been published since the 1999 Horwath review ${ }^{4}$ to answer the following questions:

(1) How has the TTM been used to describe the dietary behaviours of populations and their intentions with respect to following dietary recommendations? Have researchers been able to accurately classify participants according to stage for various dietary behaviour changes?

(2) What is the evidence for using stage-based interventions with populations to achieve positive nutritional goals and behaviours?

(3) Do valid and reliable measures exist to describe dietary behaviours using the TTM constructs other than stage of change?

\section{Identification of studies to be included}

Using a system that has been developed and applied to published literature reviews of the TTM as applied to tobacco use ${ }^{10}$, cancer screening behaviour ${ }^{12}$ and exercise ${ }^{11}$, the present body of literature on dietary behaviour was organised and evaluated. A database search was conducted using the following databases: CINAHL, Medline, Academic Search Premier, EMBASE, PsychInfo and ERIC. Combinations of the following keywords were used: transtheoretical model, stages of change, nutrition, diet, dietary behaviour, weight management, obesity and diabetes. Only original research studies published in peerreviewed journals were included. All of the studies identified were in English, although this language restriction was not specified in the search. (We recognise that there is a growing body of non-English studies of the TTM, and that it is likely that some of these address dietary behaviour.) A total of sixty-five original research studies published between 1999 (the year that the previous literature review ended) and August 2006 were identified.

\section{Organisation of the literature}

Studies were classified as population, intervention or validation based on their study design and purpose. Population studies (n 21) were either cross-sectional or longitudinal and sought to describe the dietary behaviour of 
populations using TTM constructs. Intervention studies ( $n$ 25) featured a dietary behaviour-change programme that was evaluated using TTM constructs and, in some cases, based on the TTM (i.e. a 'stage-matched' intervention). Validation studies ( $n$ 19) attempted to test the validity of applying one or more TTM constructs to dietary behaviour. Each category of studies is summarised and presented in a table.

\section{Analysis of the literature}

While the literature review is a qualitative process, we sought to make it as objective as possible to provide a useful and accurate response to the research questions guiding the present review. All studies are rated according to study design using five categories based on established criteria ${ }^{14}$. Experimental studies were clinical, controlled trials with random assignment of participants to control and intervention conditions. Quasiexperimental studies were clinical, controlled trials without random assignment. Non-experimental studies analysed the effectiveness of interventions without the use of a control group, and included cohort and case-control designs. Multiple time series studies included evaluation and comparison of participants in the absence of an intervention, such as correlation and regression analysis. Descriptive studies used cross-sectional survey designs.

The intervention studies are each assigned an internal validity rating, using previously established criteria ${ }^{14}$. Threats to internal validity are defined as a lack of any of the following: initial assembly of comparable groups, maintenance of groups throughout study, small sample size, loss to follow-up analysis or intention-to-treat analysis, evidence of the reliability and validity of measures, a clearly defined intervention, considering all important outcomes, or adjustment for confounding variables. Studies are given a rating of 'good' if they contain no significant threats to internal validity, 'fair' if they contain one threat and 'poor' if they contain two or more threats.

The body of intervention studies, as a whole, is then rated based on how strong the evidence is to support using stagebased dietary interventions, using criteria established by Anderson \& O'Donnell ${ }^{15}$. Literature is rated as conclusive if it includes many well-designed clinical controlled trials that demonstrate a cause-and-effect relationship between the intervention and the outcomes. Literature rated as acceptable includes some well-designed clinical controlled trials demonstrating a cause-and-effect relationship between the intervention and outcomes, but more studies supporting this relationship are desired. Literature considered indicative includes many non-experimental studies that suggest a cause-and-effect relationship between the intervention and outcomes; however, there are threats to internal validity with many of the studies. Literature rated as suggestive includes some non-experimental studies that suggest a cause-andeffect relationship between the intervention and outcomes, but the studies are not well designed and may suffer from threats to internal validity. Literature identified as weak does not offer valid evidence for a cause-and-effect relationship between the intervention and outcomes, although experts may believe that a relationship is plausible.

\section{Summary of the literature}

All of the studies included in the present review are summarised in one of three tables. Table 1 includes the twenty-one population studies ${ }^{16-36}$, Table 2 includes the twenty-five intervention studies ${ }^{37-61}$ and Table 3 includes the nineteen validation studies ${ }^{62-80}$. A summary of each table is presented in this section.

\section{Population studies}

A summary of the twenty-one population studies is presented in Table 1. Populations represented included: a variety of low-income, ethnic populations; populations of patients with diabetes or obesity; a representative sample of US adults; one community-based sample of adults; international populations, including Spanish and Australian samples; older populations; cardiac populations. Compared with the study populations included in the review by Horwath $^{4}$, the present group of studies provides more information on low-income populations, which received less representation in the body of literature before 1999. Importantly, the current group of studies includes a variety of specific populations, whereas the Horwath ${ }^{4}$ review included many studies using general adult samples from communities and worksites.

When considering the aggregate of data from these studies, the TTM, particularly the stage-of-change construct, was consistent in describing either measured dietary intake or food-related habits and perceptions. All twentyone studies included measures of the stage-of-change construct as applied to particular dietary behaviours, weight-loss behaviours or nutrient intakes. A minority of studies employed other TTM constructs, such as decisional balance ( $n$ 5; study numbers P8, P9, P10, P12 and P16), selfefficacy ( $n$ 6; study numbers P8, P10, P11, P16, P18 and P20) or processes of change ( $n$ 6; study numbers P4, P7, P8, P10, P15 and P20), limiting the ability to draw conclusions about the utility of these constructs.

The greatest number of studies (n 9; study numbers $\mathrm{P} 2$, P3, P4, P5, P8, P13, P17, P18 and P21) included assessments of fruit and vegetable intake. Only two studies focused on the intake of dairy or dairy products (study numbers P9 and P10). Four studies focused on broader eating patterns (study numbers P1, P12, P14 and P15), and two included portion size (study numbers P14 and P21). In relation to specific nutrients, ten studies considered dietary fat intake (study numbers P2, P5, P6, P7, P13, P16, P17, P18, P19 and P21). Finally, seven studies focused on other health-related behaviours (i.e. exercise or physical activity, smoking, alcohol use) and perceptions related to weight loss (study numbers P1, P2, P7, P11, P13, P16 and P21). Studies showed a fairly consistent pattern of increases in fruit, vegetable, or Ca intake, as well as decreases in fat intake or in the percentage of energy from fat across the stages of change, in a variety of populations. Researchers also demonstrated hypothesised relationships between later stages, such as preparation, action, and maintenance, and greater focus on health and health-related behaviours.

The prior literature review ${ }^{4}$ noted inconsistency in application of the stages of change, perhaps due to a focus 
Table 1. Summary of population studies of the transtheoretical model (TTM) as applied to dietary behaviour

\begin{tabular}{|c|c|c|c|c|c|c|}
\hline $\begin{array}{l}\text { Study no. and } \\
\text { reference }\end{array}$ & Research question & $\begin{array}{l}\text { Sample character- } \\
\text { istics }\end{array}$ & Study design & Measures & Findings & Implications \\
\hline $\begin{array}{l}\text { P1 Burke } \\
\quad \text { et al. }(2000)^{16}\end{array}$ & $\begin{array}{l}\text { Is the stage-of-change } \\
\text { construct related to } \\
\text { physical activity and } \\
\text { dietary intake valid } \\
\text { among 18-year-old } \\
\text { Australian men and } \\
\text { women? }\end{array}$ & $\begin{array}{l}\text { Volunteer sample of } \\
583 \text { subjects from } \\
\text { a prior study } \\
\text { sample }(51.6 \% \\
\text { male; response } \\
\text { rate } 67 \%)\end{array}$ & $\begin{array}{l}\text { Participants were } \\
\text { sampled from a lar- } \\
\text { ger longitudinal } \\
\text { study of cardiovas- } \\
\text { cular risk factors }\end{array}$ & $\begin{array}{l}\text { Assessments included } \\
2 \mathrm{~d} 24 \mathrm{~h} \text { diet records, } \\
\text { and a stage-of-change } \\
\text { questionnaire for var- } \\
\text { ious behaviours }^{91}\end{array}$ & $\begin{array}{l}\text { Significant increases were noted in fibre } \\
\text { intake across stages for males, and for } \\
\text { fibre intake for women. Increases were } \\
\text { also noted for fruit and vegetable } \\
\text { intake for both men and women. A NS } \\
\text { decrease in fat intake was noted in } \\
\text { men and women. Similar results were } \\
\text { noted for physical activity and fitness }\end{array}$ & $\begin{array}{l}\text { The results of this study } \\
\text { highlight the utility of } \\
\text { stages of change for } \\
\text { developing health pro- } \\
\text { motion programmes tar- } \\
\text { geted at individuals at } \\
\text { different stages. Authors } \\
\text { note the need to con- } \\
\text { sider factors influencing } \\
\text { the process of change } \\
\text { as well }\end{array}$ \\
\hline $\begin{array}{l}\text { P2 Campbell } \\
\text { et al. }(2000)^{17}\end{array}$ & $\begin{array}{l}\text { What is the relationship } \\
\text { between health risks } \\
\text { and stages of } \\
\text { change for health } \\
\text { behaviours? }\end{array}$ & $\begin{array}{l}\text { Volunteer, worksite } \\
\text { sample ( } n \text { 589; all } \\
\text { females aged } 18 \\
\text { years or older; } \\
\text { participation rate } \\
70 \% \text { ) }\end{array}$ & $\begin{array}{l}\text { This was a cross-sec- } \\
\text { tional study to } \\
\text { assess health risks } \\
\text { and behaviours in } \\
\text { relation to stages of } \\
\text { change in blue-col- } \\
\text { lar women }\end{array}$ & $\begin{array}{l}\text { Comprehensive ques- } \\
\text { tionnaire. Stages of } \\
\text { change }^{3} \text {, demo- } \\
\text { graphics, health sta- } \\
\text { tus, BMl and health } \\
\text { behaviours (including } \\
\text { smoking, exercise, } \\
\text { diet and cancer } \\
\text { screening) were } \\
\text { assessed }\end{array}$ & $\begin{array}{l}\text { Participants were distributed across } \\
\text { stages for increasing fruit and veg- } \\
\text { etable intake and decreasing fat intake. } \\
\text { No significant differences were found } \\
\text { for eating behaviours alone }\end{array}$ & $\begin{array}{l}\text { Authors suggest that the } \\
\text { stages-of-change model } \\
\text { might not be effective in } \\
\text { identifying readiness to } \\
\text { change across health } \\
\text { behaviours when } \\
\text { women consider mul- } \\
\text { tiple behaviour choices }\end{array}$ \\
\hline $\begin{array}{l}\text { P3 Clark et al. } \\
(2005)^{18}\end{array}$ & $\begin{array}{l}\text { What is the relationship } \\
\text { between stages of } \\
\text { change for exercise } \\
\text { and fruit and veg- } \\
\text { etable consumption, } \\
\text { and are they reflec- } \\
\text { tive of measures of } \\
\text { exercise, intake and } \\
\text { physical functioning } \\
\text { in an older popu- } \\
\text { lation? }\end{array}$ & $\begin{array}{l}\text { Volunteer, commu- } \\
\text { nity sample of } \\
1274 \text { older adults } \\
\text { residing in RI, USA } \\
(69.6 \% \text { female; } \\
\text { mean age } 75 \cdot 4 \\
\text { years; partici- } \\
\text { pation rate } 14 \% \text { of } \\
\text { all older adults } \\
\text { within East Provi- } \\
\text { dence, RI, USA) }\end{array}$ & $\begin{array}{l}\text { This was a descriptive } \\
\text { study meant to pro- } \\
\text { vide baseline data } \\
\text { for a large, multiple- } \\
\text { behaviour interven- } \\
\text { tion focusing on } \\
\text { regular exercise and } \\
\text { consumption of } \\
\text { fruits and veg- } \\
\text { etables in older } \\
\text { adults }\end{array}$ & $\begin{array}{l}\text { Stages-of-change ques- } \\
\text { tionnaires for exer- } \\
\text { cise }^{92} \text { and for fruit and } \\
\text { vegetable consump- }^{81} \text { tions } \\
\text { tion }^{81} \text { National Insti- } \\
\text { tutes of Health fruit } \\
\text { and vegetable intake } \\
\text { assessment, physical } \\
\text { functioning assess- } \\
\text { ment, physical activity } \\
\text { survey, and demo- } \\
\text { graphics questions } \\
\text { were used }\end{array}$ & $\begin{array}{l}\text { More than half of the sample was in action } \\
\text { or maintenance stages for both fruit } \\
\text { and vegetable consumption and for } \\
\text { exercise. Stages of change for both } \\
\text { exercise and fruit and vegetable } \\
\text { consumption were associated with } \\
\text { activity scores, servings of fruits and } \\
\text { vegetables, and physical functioning in } \\
\text { predicted directions. Stages of change } \\
\text { for both behaviours were associated } \\
\text { with each other, such that individuals in } \\
\text { higher stages for one behaviour were } \\
\text { more likely to be in higher stages of the } \\
\text { other behaviour }\end{array}$ & $\begin{array}{l}\text { In this assessment, stages } \\
\text { of change were related } \\
\text { to measures of physical } \\
\text { activity and dietary } \\
\text { intake, suggesting the } \\
\text { utility of the construct in } \\
\text { an older population }\end{array}$ \\
\hline $\begin{array}{l}\text { P4 Chung et al. } \\
\qquad(2006)^{19}\end{array}$ & $\begin{array}{l}\text { Are processes of } \\
\text { change different by } \\
\text { stages of change for } \\
\text { fruit and vegetable } \\
\text { intake among col- } \\
\text { lege women? }\end{array}$ & $\begin{array}{l}\text { Volunteer sample of } \\
236 \text { college } \\
\text { women (age 18- } \\
24 \text { years; partici- } \\
\text { pation rate } 36 \%)\end{array}$ & $\begin{array}{l}\text { This was a cross-sec- } \\
\text { tional study using a } \\
\text { convenience } \\
\text { sample of college- } \\
\text { aged women }\end{array}$ & $\begin{array}{l}\text { Stages-of-change ques- } \\
\text { tionnaire for fruit and } \\
\text { vegetable consump- } \\
\text { tion }{ }^{33} \text {, processes-of- } \\
\text { change question- } \\
\text { naire }{ }^{94} \text {, and a } 3 \mathrm{~d} \text { food } \\
\text { record were used }\end{array}$ & $\begin{array}{l}\text { Intakes of fruits and vegetables were } \\
\text { significantly different by stage, such } \\
\text { that intake was higher in the combined } \\
\text { action and maintenance stage com- } \\
\text { pared with the combined precontem- } \\
\text { plation and contemplation stage. } \\
\text { Those in precontemplation or contem- } \\
\text { plation used the process of self-re- } \\
\text { evaluation more often, while those in } \\
\text { action or maintenance used counter- } \\
\text { conditioning more often }\end{array}$ & $\begin{array}{l}\text { Fruit and vegetable intake } \\
\text { was significantly related } \\
\text { to stage of change in } \\
\text { this population. Pro- } \\
\text { cesses of change also } \\
\text { related to stages of } \\
\text { change, suggesting the } \\
\text { utility of targeting inter- } \\
\text { ventions to particular } \\
\text { processes based on } \\
\text { stage }\end{array}$ \\
\hline
\end{tabular}




\begin{tabular}{|c|c|c|c|c|c|c|}
\hline $\begin{array}{l}\text { Study no. and } \\
\text { reference }\end{array}$ & Research question & $\begin{array}{l}\text { Sample character- } \\
\text { istics }\end{array}$ & Study design & Measures & Findings & Implications \\
\hline $\begin{array}{l}\text { P5 Frame et al. } \\
\qquad(2001)^{20}\end{array}$ & $\begin{array}{l}\text { What is the stage dis- } \\
\text { tribution for cardiac } \\
\text { patients in a rehabi- } \\
\text { litation programme } \\
\text { regarding dietary fat } \\
\text { and fruit and veg- } \\
\text { etable intake? }\end{array}$ & $\begin{array}{l}\text { Volunteer sample of } \\
226 \text { cardiac } \\
\text { patients from a } \\
\text { rehabilitation } \\
\text { centre }(72 \cdot 1 \% \\
\text { male; } 89.9 \% \\
\text { white; mean age } \\
63.5 \text { years; par- } \\
\text { ticipation rate } \\
93 \%)\end{array}$ & $\begin{array}{l}\text { This was a cross-sec- } \\
\text { tional, descriptive } \\
\text { study using a con- } \\
\text { venience sample of } \\
\text { patients in cardiac } \\
\text { rehabilitation asses- } \\
\text { sing reduction of } \\
\text { dietary fat and } \\
\text { increase in fruit and } \\
\text { vegetable consump- } \\
\text { tion }\end{array}$ & $\begin{array}{l}\text { Stages of change for fruit } \\
\text { and vegetable con- } \\
\text { sumption } \\
\text { were und a FFQ }\end{array}$ & $\begin{array}{l}\text { Of subjects, } 78.7 \% \text { were in action or } \\
\text { maintenance for decreasing fat intake, } \\
\text { while only } 15.6 \% \text { were in action or } \\
\text { maintenance for increasing fruit and } \\
\text { vegetable intake. Overall, percentage } \\
\text { energy from fat decreased, and fruit } \\
\text { and vegetable consumption increased } \\
\text { across stages }\end{array}$ & $\begin{array}{l}\text { These results demon- } \\
\text { strated contrasting } \\
\text { stages of change for two } \\
\text { heart-health-related } \\
\text { behaviours. As such, } \\
\text { interventions should } \\
\text { focus on differing stage- } \\
\text { matched methods for } \\
\text { various behaviours }\end{array}$ \\
\hline $\begin{array}{l}\text { P6 Frenn et al. } \\
\qquad(2005)^{21}\end{array}$ & $\begin{array}{l}\text { Do stages of change } \\
\text { predict percentage } \\
\text { dietary fat? }\end{array}$ & $\begin{array}{l}\text { Volunteer sample of } \\
100 \text { African-Amer- } \\
\text { ican and Hispanic } \\
7 \text { th graders in a } \\
\text { school setting } \\
\text { (mean age } 12 \cdot 8 \\
\text { years; } 52 \% \\
\text { female; partici- } \\
\text { pation rate } 71 \% \text { ) }\end{array}$ & $\begin{array}{l}\text { This was a descriptive, } \\
\text { cross-sectional } \\
\text { study assessing } \\
\text { predictive power of } \\
\text { stages of change }\end{array}$ & $\begin{array}{l}\text { A food habits question- } \\
\text { naire and a stage-of- } \\
\text { change question- } \\
\text { naire } \\
\text { 82 were used }\end{array}$ & $\begin{array}{l}\text { Stage of change significantly predicted } \\
\text { percentage energy as dietary fat }\end{array}$ & $\begin{array}{l}\text { Stages-of-change con- } \\
\text { struct might be reflective } \\
\text { of dietary fat habits for } \\
\text { this population }\end{array}$ \\
\hline $\begin{array}{l}\text { P7 Frenn \& Malin } \\
(2003)^{22}\end{array}$ & $\begin{array}{l}\text { What constructs and } \\
\text { processes of } \\
\text { change are related } \\
\text { to stages of change } \\
\text { for a low-fat diet in } \\
\text { low- to middle- } \\
\text { income adoles- } \\
\text { cents? }\end{array}$ & $\begin{array}{l}\text { Volunteer sample of } \\
221 \text { children in } \\
\text { sixth, seventh, or } \\
\text { eighth grade } \\
\text { (57.5\% male; par- } \\
\text { ticipation rate not } \\
\text { reported) }\end{array}$ & $\begin{array}{l}\text { This was a descriptive, } \\
\text { cross-sectional } \\
\text { study assessing } \\
\text { factors related to } \\
\text { stages of change for } \\
\text { a low-fat diet }\end{array}$ & $\begin{array}{l}\text { Non-validated access to } \\
\text { healthy foods ques- } \\
\text { tionnaire, modified } \\
\text { stages-of-change } \\
\text { questionnaire }{ }^{82}, \text { food } \\
\text { habits questionnaire, } \\
\text { pros and cons instru- } \\
\text { ment for a low-fat diet, } \\
\text { temptation scale for } \\
\text { low-fat foods, and a } \\
\text { low-fat diet process-of- } \\
\text { change questionnaire } \\
\text { were used }\end{array}$ & $\begin{array}{l}\text { Percentage fat in diet decreased signifi- } \\
\text { cantly across stages of change, while } \\
\text { access to low-fat foods and processes } \\
\text { related to a low-fat diet increased across } \\
\text { stages. Exercise-related processes also } \\
\text { increased significantly across stages. } \\
\text { Access to low-fat foods and gender were } \\
\text { identified as antecedents of a diet low in } \\
\text { fat }\end{array}$ & $\begin{array}{l}\text { Results suggest that } \\
\text { access to low-fat foods } \\
\text { might be an important } \\
\text { aspect of future stages- } \\
\text { of-change-based inter- } \\
\text { ventions. Stage-appro- } \\
\text { priate processes are } \\
\text { also important to con- } \\
\text { sider }\end{array}$ \\
\hline $\begin{array}{l}\text { P8 Greene et al. } \\
\qquad(2004)^{23}\end{array}$ & $\begin{array}{l}\text { What are the differ- } \\
\text { ences in demo- } \\
\text { graphic and } \\
\text { psychological vari- } \\
\text { ables related to } \\
\text { fruits and veg- } \\
\text { etables across the } \\
\text { stages of change? }\end{array}$ & $\begin{array}{l}\text { Volunteer sample of } \\
1254 \text { community } \\
\text { residents (mean } \\
\text { age } 75.4 \text { years; } \\
\text { mean } \mathrm{BMl} \\
27.2 \mathrm{~kg} / \mathrm{m}^{2} ; \\
69.8 \% \text { female; } \\
\text { participation rate } \\
\text { reported else- } \\
\text { where) }\end{array}$ & $\begin{array}{l}\text { This was a descriptive } \\
\text { study including par- } \\
\text { ticipants from the } \\
\text { SENIOR project }\end{array}$ & $\begin{array}{l}\text { Two validated FFQ, and } \\
\text { questionnaires asses- } \\
\text { sing stages of change } \\
\text { for fruit and vegetable } \\
\text { consumption }{ }^{81} \text {, deci- } \\
\text { sional balance, pro- } \\
\text { cesses of change, and } \\
\text { self-efficacy were } \\
\text { used }\end{array}$ & $\begin{array}{l}15 \% \text { were in precontemplation, } 64 \% \text { were } \\
\text { in maintenance and fewer than } 2 \% \text { were } \\
\text { in contemplation or action; fruit and } \\
\text { vegetable consumption increased line- } \\
\text { arly across stages (explaining } 15-17 \% \\
\text { of the variance), with variable increases } \\
\text { in decisional balance, processes of } \\
\text { change, and self-efficacy }\end{array}$ & $\begin{array}{l}\text { The study results sup- } \\
\text { ported the utility of self- } \\
\text { assessed number of } \\
\text { servings for stage-of- } \\
\text { change classification in } \\
\text { this population. Authors } \\
\text { suggested a focus on } \\
\text { perceived benefits of } \\
\text { fruit and vegetable con- } \\
\text { sumption in older adults } \\
\text { when designing inter- } \\
\text { ventions }\end{array}$ \\
\hline
\end{tabular}


P9 Gulliver \& Horwath $(2001)^{24}$

How does decisional balance relate to stages of change for milk consumption among women in New Zealand?

$\begin{array}{ll}\text { P10 Gulliver \& } & \text { What is the stage dis- } \\ \text { Horwath } & \text { tribution for New } \\ (2001)^{25} & \text { Zealand women } \\ & \text { regarding readiness } \\ & \text { to meet milk con- } \\ & \text { sumption rec- }\end{array}$

\begin{tabular}{|c|c|c|}
\hline $\begin{array}{l}\text { P11 Hawkins et al. } \\
\qquad(2001)^{26}\end{array}$ & $\begin{array}{l}\text { Can the stages-of- } \\
\text { change model } \\
\text { regarding intentions } \\
\text { for weight loss be } \\
\text { generalised to over- } \\
\text { weight and obese } \\
\text { rural African-Ameri- } \\
\text { can women, and } \\
\text { what factors predict } \\
\text { stages of change in } \\
\text { this population? }\end{array}$ & $\begin{array}{l}\text { Random sample of } \\
200 \text { African-Amer- } \\
\text { ican women aged } \\
\text { less than } 40 \text { years } \\
\text { from a prior study } \\
\text { sample }(71 \% \\
\text { overweight or } \\
\text { obese; partici- } \\
\text { pation rate } 76 \%)\end{array}$ \\
\hline $\begin{array}{l}\text { P12 Lea et al. } \\
\quad(2006)^{27}\end{array}$ & $\begin{array}{l}\text { What is the readiness } \\
\text { to change to a plant- } \\
\text { based diet in a ran- } \\
\text { dom sample of Aus- } \\
\text { tralian adults? }\end{array}$ & $\begin{array}{l}\text { Random sample of } \\
415 \text { Australian } \\
\text { adults }(59.4 \% \\
\text { female; partici- } \\
\text { pation rate } 51 \%)\end{array}$ \\
\hline
\end{tabular}

Random sample of 704 females selected from national electoral rolls (age 25-70 years; participation rate $80 \%$ )
Participants were sampled from a larger study investigating application of the TTM and milk consumption. $\mathrm{Pa}$ consumption. Participants comple
mailed surveys mailed surveys
related to meeting milk consumption goals (either two servings or four servings per d) and a short phone interview for stage assessment

Participants were sampled from a larger study investigating application of the TTM and milk consumption. Par-

ticipants completed mailed surveys related to meeting milk consumption goals (either two or four servings per day) and a short phone interview for stage assessment

Participants were sampled from the
Alliance of Black Alliance of Black Project. Datawere Project. Data were collected in person or over the phone

$\mathrm{FQ}$, stages of change for milk consumption (used non-validated algorithm based on DiClemente et al. ${ }^{3}$, demographic, health conditions, and height and weight data were collected

Stages-of-change questionnaire (non-validated algorithm based on DiClemente et al. ${ }^{3}$ ), $\mathrm{BMI}$, demographic information, and socia expectations for weight loss were measured

This was a descriptive, cross-sectional study to assess stages of change and decisional balance related to a plant-based diet

A mailed questionnaire newly developed stages-of-change (adapted from Povey et al. ${ }^{95}$ ) and decisionalbalance assessments,
$27 \%$ were in precontemplation, $4 \%$ were $17.6 \%$ of the variance. Only a smal was used that included and an eating habits questionnaire was used in contemplation, $4 \%$ were in preparation, $4 \%$ were in action and $61 \%$ were in maintenance. Perceived benefits were positively correlated with $\mathrm{Ca}$ intake while perceived barriers were positively associated with weight. Differences existed in perceived benefits across stages and explained percentage of the variance was explained by differences in barriers across stages

$73 \%$ of women were in the precontemplation stage for meeting the recommendation of two servings/d. Greater than $80 \%$ were in precontemplation for consuming four servings/d. Mean $\mathrm{Ca}$ intakes increased signifi-

cantly across stages

$30 \%$ were in precontemplation, $15 \%$ were in contemplation, $48 \%$ were in preparation, $4 \%$ were in action, and $3 \%$ were in maintenance. Education level, social expectations, BMI and positive aspects of weight loss predicted stages of change

Results regarding decisional balance suggest a focus on perceived benefits of milk consump-

tion for women in

precontemplation, as well as a focus on how to achieve milk consumption goals despite perceived barriers

Results demonstrated the feasibility of a stage-of change assessment too related to milk product consumption in this population. The assessment tool corresponded with the FFQ results for Ca intake

This study demonstrated the applicability of the TTM to weight-loss intentions among African-American women. It also described important predictors of stages of change. This information is useful in further developing interventions to help AfricanAmerican women progress through stages

$58 \%$ were in precontemplation, $14 \%$ were in contemplation or preparation, and $28 \%$ were in action or maintenance; those in higher stages recognised more benefits and fewer barriers than those in lower stages 


\begin{tabular}{|c|c|c|c|c|c|c|}
\hline $\begin{array}{l}\text { Study no. and } \\
\text { reference }\end{array}$ & Research question & $\begin{array}{l}\text { Sample character- } \\
\text { istics }\end{array}$ & Study design & Measures & Findings & Implications \\
\hline $\begin{array}{l}\text { P13 Logue et al. } \\
\quad(2000)^{28}\end{array}$ & $\begin{array}{l}\text { How do stages of } \\
\text { change vary for } \\
\text { obese primary-care } \\
\text { patients regarding fat } \\
\text { intake, portion con- } \\
\text { trol, vegetable } \\
\text { intake, fruit intake, } \\
\text { physical activity, and } \\
\text { planned exercise, } \\
\text { and how do stages } \\
\text { relate to anthropo- } \\
\text { metric data? }\end{array}$ & $\begin{array}{l}\text { Volunteer sample of } \\
284 \text { obese pri- } \\
\text { mary-care } \\
\text { patients from an } \\
\text { obesity care } \\
\text { centre (mean age } \\
46.5 \text { years; } 81 \% \\
\text { female; mean BMl } \\
35.9 \mathrm{~kg} / \mathrm{m}^{2} ; \text { par- } \\
\text { ticipation rate not } \\
\text { reported) }\end{array}$ & $\begin{array}{l}\text { Researchers gathered } \\
\text { girth measurements } \\
\text { and assessed } \\
\text { readiness to change } \\
\text { via a survey }\end{array}$ & $\begin{array}{l}\text { Stages-of-change } \\
\text { assessment (non-vali- } \\
\text { dated algorithm based } \\
\text { on DiClemente et al. } \\
1991^{3} \text { ), girth and BMI } \\
\text { were measured }\end{array}$ & $\begin{array}{l}\text { Though preparation stage was the most } \\
\text { frequent for numerous health beha- } \\
\text { viours, stages were variable by subject } \\
\text { across behaviours. For five of six } \\
\text { health behaviours, stage of change } \\
\text { was associated with both waist girth } \\
\text { and BMI such that decreases occurred } \\
\text { across stage level }\end{array}$ & $\begin{array}{l}\text { Because of the diversity of } \\
\text { stage level in obese } \\
\text { primary-care patients, } \\
\text { treatment for obesity } \\
\text { must be highly indivi- } \\
\text { dualised. The TTM can } \\
\text { provide the foundation } \\
\text { for tailoring treatment }\end{array}$ \\
\hline $\begin{array}{l}\text { P14 Lopez-Azpiazu } \\
\text { et al. }(2000)^{29}\end{array}$ & $\begin{array}{l}\text { What is the stage dis- } \\
\text { tribution within } \\
\text { Spanish adults } \\
\text { regarding healthy } \\
\text { eating patterns (age } \\
>15 \text { years)? }\end{array}$ & $\begin{array}{l}\text { Random sample of } \\
1009 \text { Spanish } \\
\text { adults (59.7\% } \\
\text { male; participation } \\
\text { rate } 88 \%)\end{array}$ & $\begin{array}{l}\text { This was a cross-sec- } \\
\text { tional study asses- } \\
\text { sing stages of } \\
\text { dietary change and } \\
\text { behaviours and atti- } \\
\text { tudes toward } \\
\text { healthy eating using } \\
\text { a published ques- } \\
\text { tionnaire }\end{array}$ & $\begin{array}{l}\text { Stages of change ques- } \\
\text { tionnaire (developed } \\
\text { for this study) admi- } \\
\text { nistered with estab- } \\
\text { lished interview } \\
\text { protocol, and ques- } \\
\text { tions on beliefs about } \\
\text { healthy eating and } \\
\text { food choice were used }\end{array}$ & $\begin{array}{l}56 \% \text { were in precontemplation, } 7.9 \% \text { were } \\
\text { dynamic (or in preparation), } 28.3 \% \text { were } \\
\text { in maintenance and } 7.7 \% \text { were in } \\
\text { relapse (or termination). Generally, } \\
\text { younger females were classified in } \\
\text { stages beyond precontemplation. } \\
\text { Those in preparation or maintenance } \\
\text { more often cited 'trying to eat healthy' as } \\
\text { an influence on the foods they chose to } \\
\text { eat. Most participants in precontempla- } \\
\text { tion and maintenance felt no need to } \\
\text { change their diets }\end{array}$ & $\begin{array}{l}\text { The adult Spanish popu- } \\
\text { lation can successfully } \\
\text { be classified by stages } \\
\text { of change. Thus, the } \\
\text { TTM might be useful in } \\
\text { developing more tar- } \\
\text { geted nutritional inter- } \\
\text { ventions }\end{array}$ \\
\hline $\begin{array}{l}\text { P15 Nothwehr et al. } \\
\qquad(2006)^{30}\end{array}$ & $\begin{array}{l}\text { What is the distribution } \\
\text { of behavioural strat- } \\
\text { egies for healthful } \\
\text { eating across the } \\
\text { stages of change, } \\
\text { and do stages pre- } \\
\text { dict use of strategies } \\
\text { over } 1 \text { year? }\end{array}$ & $\begin{array}{l}\text { Volunteer sample of } \\
407 \text { adults in rural } \\
\text { IA, USA ( } 56.8 \% \\
\text { female; response } \\
\text { rate } 25 \%)\end{array}$ & $\begin{array}{l}\text { This was a cross-sec- } \\
\text { tional study with a 1- } \\
\text { year follow-up to } \\
\text { assess dietary } \\
\text { behaviour strategies }\end{array}$ & $\begin{array}{l}\text { FFQ, non-validated sta- } \\
\text { ging questions and } \\
\text { previously developed } \\
\text { behavioural strategy } \\
\text { assessments were } \\
\text { used }\end{array}$ & $\begin{array}{l}\text { Significant increases in use of behavioural } \\
\text { strategies for healthful eating were } \\
\text { noted across stages. Stages did not } \\
\text { consistently predict, however, changes } \\
\text { in use of strategies over } 1 \text { year }\end{array}$ & $\begin{array}{l}\text { These data are not conclus- } \\
\text { ive as to the predictive } \\
\text { strength of stages of } \\
\text { change for dietary strat- } \\
\text { egies in the absence of } \\
\text { an intervention. That } \\
\text { strategies were related to } \\
\text { individual stages might } \\
\text { suggest useful interven- } \\
\text { tion strategies for future } \\
\text { studies }\end{array}$ \\
\hline $\begin{array}{l}\text { P16 O'Hea et al. } \\
(2003)^{31}\end{array}$ & $\begin{array}{l}\text { What are the sex } \\
\text { differences among } \\
\text { various constructs } \\
\text { of the TTM for diet- } \\
\text { ary fat reduction and } \\
\text { other health habits? }\end{array}$ & $\begin{array}{l}\text { Volunteer sample of } \\
554 \text { low-income } \\
\text { individuals from } \\
\text { primary-care } \\
\text { clinics }(80.7 \% \\
\text { female; partici- } \\
\text { pation rate not } \\
\text { reported) }\end{array}$ & $\begin{array}{l}\text { This was a cross-sec- } \\
\text { tional comparison of } \\
\text { sexes across TTM } \\
\text { constructs }\end{array}$ & $\begin{array}{l}\text { Stages-of-change ques- } \\
\text { tionnaire }^{82}, \text { self-effi- } \\
\text { cacy questionnaire } \\
\text { and decisional-bal- } \\
\text { ance questionnaire } \\
\text { were used }\end{array}$ & $\begin{array}{l}\text { A NS difference between sexes across } \\
\text { measures was found }\end{array}$ & $\begin{array}{l}\text { These data are not con- } \\
\text { sistent with previous } \\
\text { findings. Sex differ- } \\
\text { ences might not be } \\
\text { accurately assessed } \\
\text { using these TTM- } \\
\text { related assessment } \\
\text { tools in relation to fat } \\
\text { intake }\end{array}$ \\
\hline
\end{tabular}


P17 Pullen \& Walker (2002) $)^{32}$

\section{What is the stage dis-} tribution for older rural women

regarding intake of servings from all food groups (of the old Food Guide Pyramid)?

$\begin{array}{cl}\text { P18 Tassell \& Flett } & \text { How do social physique } \\ (2005)^{33} & \text { anxiety, self-effi- } \\ & \text { cacy, common bar- } \\ & \text { riers to dietary } \\ \text { change, and food } & \text { security compare } \\ \text { across stages of } \\ \text { change for dietary } \\ \text { fat reduction and } \\ \text { increasing fruit and } \\ \text { vegetable consump- } \\ \text { tion? }\end{array}$

\begin{tabular}{|c|c|c|c|}
\hline $\begin{array}{l}\text { P19 Vallis et al. } \\
(2003)^{34}\end{array}$ & $\begin{array}{l}\text { What is the stage dis- } \\
\text { tribution for over- } \\
\text { weight diabetic } \\
\text { individuals in } \\
\text { relation to demo- } \\
\text { graphics and eating- } \\
\text { related factors, } \\
\text { among other vari- } \\
\text { ables? }\end{array}$ & $\begin{array}{l}\text { Random sample of } \\
768 \text { overweight } \\
\text { patients with type } \\
1 \text { or type } 2 \text { dia- } \\
\text { betes from a prior } \\
\text { study sample } \\
(51 \cdot 1 \% \text { female; } \\
\text { mean age } 47.5 \\
\text { years; mean BMI } \\
32 \cdot 8 \mathrm{~kg} / \mathrm{m}^{2} ; \text { par- } \\
\text { ticipation rate } \\
\text { reported else- } \\
\text { where) }\end{array}$ & $\begin{array}{l}\text { Participants from the } \\
\text { Diabetes Stages of } \\
\text { Change trial were } \\
\text { assessed for stages } \\
\text { of change for } \\
\text { healthy low-fat eat- } \\
\text { ing, eating-related } \\
\text { factors, and demo- } \\
\text { graphics }\end{array}$ \\
\hline $\begin{array}{l}\text { P20 Van Duyn et al. } \\
\qquad(2001)^{35}\end{array}$ & $\begin{array}{l}\text { What is the stage dis- } \\
\text { tribution for a repre- } \\
\text { sentative sample of } \\
\text { the US adult popu- } \\
\text { lation regarding a } \\
\text { diet high in fruits and } \\
\text { vegetables? }\end{array}$ & $\begin{array}{l}\text { Random sample of } \\
2605 \text { US adults } \\
\text { from a random } \\
\text { digit dial survey } \\
\text { (52\% female; } \\
\text { response rate } \\
44.5 \%)\end{array}$ & $\begin{array}{l}\text { A phone survey was } \\
\text { conducted to gather } \\
\text { demographic data } \\
\text { and to assess fruit } \\
\text { and vegetable con- } \\
\text { sumption and } \\
\text { stages of change }\end{array}$ \\
\hline
\end{tabular}

Volunteer sample of Cross-sectiona 111 Maori women from New Zealand (mean age 36 years; participation rate not reported)

ncreasing fruit and vegetable consump-

vegetables?
Behavioural risk factor surveillance system survey assessment of eating behaviours,

stage of eating adherence questionnaire (developed in this study, in relation to fat intake, fruit and vegetable intake, and grain intake), and stage of exercise adherence questionnaire were used naire for die naire for dietary fat of-change questionnaire for fruit and tion and dietary fat modification $^{81}$, the Barriers to Dietary Change questionnaire, a social physique anxiety scale, tionnaire, and demographic information

were collected

change questionnaire

for dietary fat

reduction ${ }^{82}$ were used

Stages-of-change questionnaire for fruit and vegetable consumption $^{96}$ and a 'five a day' FFQ were used vegetable consumpfood security ques-
For fat intake, $46.1 \%$ were in maintenance. For fruit and vegetable intake, $53.1 \%$ were in maintenance, and for grain intake, $37.5 \%$ were in maintenance

Dietary fat intake and barriers to fruit intake were significantly lower, and self-efficacy for maintaining a healthy diet was significantly higher, across stages for fruit and vegetable consumption. Similar results were found across stages for reducing fat intake

For stage of readiness to change regarding healthy eating, $10.2 \%$ were in precontemplation, $25.0 \%$ were in contemplation, $27.2 \%$ were in preparation, $5.8 \%$ were in action, and

$31.8 \%$ were in maintenance. Generally, for type 1 diabetics, those in action and maintenance had the lowest percentage energy from fat as well as the highest number of servings of vegetables. For type 2 diabetics, women and married participants were more often in later stages than men or single participants

$47 \%$ were in action. Significant differences existed across stages for total consumption of fruits and vegetables with about one serving increases from contemplation or preparation to action and from action to maintenance.

However, stages of change alone accounted for variance in consumption
Significant differences existed among stages for each food group. Thus, TTM-based targeted materials should be used for interventions

Dietary self-efficacy increases across stages of change for dietary goals and thus should be considered in future interventions. Barriers, such as lack of convenience and taste issues, should also be considered in planning effective interventions using the stages-ofchange construc

Healthy eating increased across stages for participants, suggesting the staging done in this study was reflective of behaviou

Stages of change are related to fruit and vegetable consumption and a variety of constructs probably are important for movement across stages 


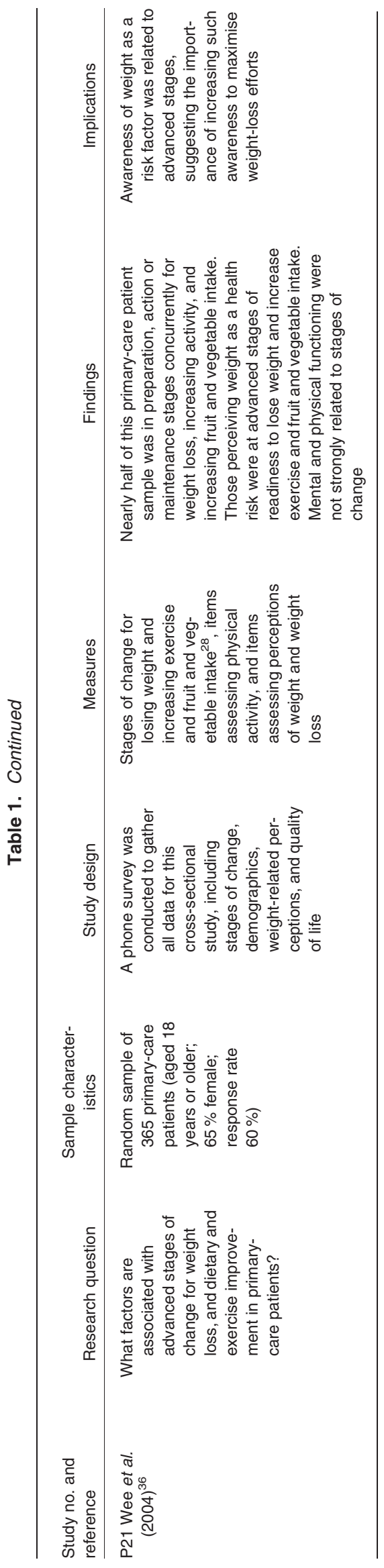

on nutrients rather than foods. In the body of literature reviewed in the present review, the focus was on foods, which might explain the improved consistency in staging algorithms. In fact, of the twenty-one studies reviewed, only two (study numbers P15 and P16) elicited data that either did not support the TTM as a useful descriptive tool or were inconclusive. It is interesting to note that both studies included stages-of-change assessment of nutrient intake (i.e. fat) alone, or along with, stages-of-change assessment for fruit and vegetable intake. Also, stages of change might not, according to one study, be effective in identifying differences between sexes; however, the results of this study were not reflective of results of previous studies in which sex differences have been successfully measured.

Even though the majority of studies successfully utilised the TTM and its constructs in describing various populations, studies employed different techniques for assessment of dietary intake, nutrition-related perceptions, or stages-of-change determination. A total of eighteen different algorithms for a variety of health behaviours were used among the population studies in Table 1. Seven of the reviewed studies included novel staging mechanisms. The staging algorithms used most often included one developed by Laforge $e t a l .{ }^{81}$ for fruit and vegetable intake and one developed by Greene \& Rossi ${ }^{82}$ for low-fat diets. Of those studies that included dietary intake or habits assessments, eight utilised some form of a FFQ (study numbers P2, P3, P9, P10, P15, P17, P19 and P20), two used a $3 \mathrm{~d}$ food record (study numbers $\mathrm{P} 4$ and $\mathrm{P} 5$ ), two used a $24 \mathrm{~h}$ recall (study numbers P1 and P8) and four included assessments of dietary habits or behaviours (study numbers P6, P7, P12 and P18).

\section{Intervention studies}

A summary of the twenty-five intervention studies is presented in Table 2. The earliest study was published in 2000 and the most recent in 2006. Of the twenty-five studies, fifteen used experimental designs, four were quasiexperimental and six used non-experimental designs. All but one of the nineteen experimental or quasi-experimental studies had an internal validity rating of good or fair. Populations included low-income adults $(n 4)$, primary-care patients ( $n$ 8), African-Americans ( $n 2)$, native Hawaiians ( $n$ 1 ), Canadian adults ( $n 1)$, British adults ( $n 1)$, German adults $(n 1)$, Dutch adults ( $n$ 3), Hispanic mothers (largely migrant farm workers) ( $n$ 1), denture-wearers $(n 1)$, patients on cholesterol-lowering drugs $(n 1)$, type 2 diabetics $(n 4)$, overweight adults ( $n$ 3), middle-school students ( $n$ 1), parents $(n 2)$ and undergraduate students ( $n 2)$. In assessing TTM constructs, twenty-four studies focused primarily on stage of change and one focused primarily on processes of change.

Studies varied according to the dietary habits they attempted to change and measure. It is important to note that dietary behaviour is not one behaviour, but a collection of many specific behaviours. All but one study focused on one or more specific behaviours, often using multiple staging algorithms, each designed to measure a specific dietary behaviour. Fifteen studies measured reductions in dietary fat, seven studies assessed fruit and vegetable intake, two 
Table 2. Summary of intervention studies of the transtheoretical model (TTM) as applied to dietary behaviour

\begin{tabular}{|c|c|c|c|c|c|c|}
\hline $\begin{array}{l}\text { Study no. and } \\
\text { reference }\end{array}$ & Research question & Sample characteristics & Intervention & Measures & Findings & Implications \\
\hline $\begin{array}{l}\text { 11 Armitage } \\
(2006)^{37} \\
\text { Experimental } \\
\text { study } \\
\text { Fair rating }\end{array}$ & $\begin{array}{l}\text { Does an intervention } \\
\text { using implemen- } \\
\text { tation intentions } \\
\text { promote stage } \\
\text { progression and } \\
\text { prevent relapse } \\
\text { for eating a low-fat } \\
\text { diet? }\end{array}$ & $\begin{array}{l}\text { British employees ( } n \\
729 ; 72 \% \text { female; } \\
378 \text { in intervention } \\
\text { group; } 351 \text { in control } \\
\text { group; retention rate } \\
59 \% \text { ) }\end{array}$ & $\begin{array}{l}\text { Implementation intentions are } \\
\text { different from behavioural } \\
\text { intentions, as they identify } \\
\text { specific conditions under } \\
\text { which a new behaviour will be } \\
\text { performed. They may or may } \\
\text { not be stage-matched. The } \\
\text { intervention group was asked } \\
\text { to independently create their } \\
\text { own criteria for when, how and } \\
\text { where they would eat low-fat } \\
\text { foods instead of high-fat } \\
\text { foods. The control group was } \\
\text { not asked to do this }\end{array}$ & $\begin{array}{l}\text { Baseline and 1-month } \\
\text { surveys assessed } \\
\text { stage of change }{ }^{3} \text {, } \\
\text { behavioural inten- } \\
\text { tion, attitude, per- } \\
\text { ceived control, } \\
\text { subjective norm, } \\
\text { and dietary intake } \\
\text { using a FFQ }\end{array}$ & $\begin{array}{l}\text { In } 1 \text { month, } 20.6 \% \text { of all par- } \\
\text { ticipants moved forward by } \\
\text { one or more stages, } 14.7 \% \\
\text { regressed and } 64.6 \% \\
\text { stayed in the same stage. } \\
\text { Those in the intervention } \\
\text { group were significantly } \\
\text { more likely to progress } \\
\text { forward in stage; however, } \\
\text { stage regression rates were } \\
\text { similar for both control and } \\
\text { intervention groups }\end{array}$ & $\begin{array}{l}\text { Interventions using implemen- } \\
\text { tation intentions require no } \\
\text { direction from professionals } \\
\text { and are less expensive to } \\
\text { offer. It is difficult to say } \\
\text { whether or not this was a } \\
\text { stage-matched intervention, } \\
\text { as the participants them- } \\
\text { selves designed their own } \\
\text { interventions and the } \\
\text { researchers did not review } \\
\text { their plans. An interesting } \\
\text { question for further research } \\
\text { is whether or not partici- } \\
\text { pants set behavioural cri- } \\
\text { teria for themselves that are } \\
\text { matched to their stages }\end{array}$ \\
\hline $\begin{array}{l}\text { 12 Auslander et al. } \\
\text { (2002) } \\
\text { Experimental } \\
\text { study } \\
\text { Good rating }\end{array}$ & $\begin{array}{l}\text { Can a culturally sen- } \\
\text { sitive, peer-led } \\
\text { programme } \\
\text { reduce the risk of } \\
\text { type } 2 \text { diabetes } \\
\text { among low- } \\
\text { income African- } \\
\text { American } \\
\text { women? }\end{array}$ & $\begin{array}{l}\text { Overweight African- } \\
\text { American women ( } n \\
\text { 294; age } 25-55 \\
\text { years; } 138 \text { in inter- } \\
\text { vention group; } 156 \\
\text { in control group; } \\
\text { retention rate } \\
73.7 \%)\end{array}$ & $\begin{array}{l}\text { Eat Well, Live Well Nutrition } \\
\text { Program is stage-matched. } \\
\text { Intervention subjects partici- } \\
\text { pated in six group sessions } \\
\text { and six individual sessions } \\
\text { with a lay peer educator. } \\
\text { Control subjects received a } \\
\text { self-help workbook }\end{array}$ & $\begin{array}{l}\text { Baseline and 3-month } \\
\text { post-programme } \\
\text { interviews assessed } \\
\text { behaviour, knowl- } \\
\text { edge, attitudes, fat } \\
\text { consumption and } \\
\text { body weight. The } \\
\text { staging of eating } \\
\text { patterns assess- } \\
\text { ment }{ }^{97} \text { and a FFQ } \\
\text { were also used }\end{array}$ & $\begin{array}{l}\text { Intervention participants sig- } \\
\text { nificantly reduced their fat } \\
\text { intake, increased their } \\
\text { intake of low-fat foods, and } \\
\text { showed higher levels of skill, } \\
\text { knowledge and more posi- } \\
\text { tive attitudes than did control } \\
\text { group participants. No sig- } \\
\text { nificant differences were } \\
\text { found in BMl or weight loss } \\
\text { between the two groups }\end{array}$ & $\begin{array}{l}\text { A stage-based intervention was } \\
\text { effective in reducing beha- } \\
\text { vioural risks related to dia- } \\
\text { betes among African- } \\
\text { American women. It also } \\
\text { resulted in significant stage } \\
\text { transitions from pre-action } \\
\text { to action stages. It did not } \\
\text { result in significant changes } \\
\text { in body weight, although this } \\
\text { was not its intention }\end{array}$ \\
\hline $\begin{array}{l}\text { I3 Bradbury et al. } \\
(2006)^{39} \\
\text { Experimental } \\
\text { study } \\
\text { Fair rating }\end{array}$ & $\begin{array}{l}\text { Does a counselling- } \\
\text { based intervention } \\
\text { offered in dental } \\
\text { offices lead to an } \\
\text { increase in fruit } \\
\text { and vegetable } \\
\text { consumption } \\
\text { among denture- } \\
\text { wearers? }\end{array}$ & $\begin{array}{l}\text { Patients who wear } \\
\text { dentures ( } n 58 ; \text { age } \\
45-88 \text { years; thirty } \\
\text { in intervention } \\
\text { group; twenty-eight } \\
\text { in control group; } \\
\text { retention rate } 87 \%)\end{array}$ & $\begin{array}{l}\text { Intervention participants received } \\
\text { two stage-matched counsel- } \\
\text { ling sessions as part of dental } \\
\text { visits. Control group partici- } \\
\text { pants received usual care }\end{array}$ & $\begin{array}{l}\text { Participants were } \\
\text { assessed at base- } \\
\text { line and } 6 \text { weeks. } \\
\text { Measures included } \\
\text { stage of change }{ }^{98} \\
\text { dietary intake and } \\
\text { chewing ability }\end{array}$ & $\begin{array}{l}\text { Intervention participants were } \\
\text { significantly more likely to } \\
\text { move into action or main- } \\
\text { tenance than were control } \\
\text { participants. Chewing ability } \\
\text { improved for both groups, } \\
\text { though }\end{array}$ & $\begin{array}{l}\text { Wearing dentures poses } \\
\text { unique obstacles to eating } \\
\text { foods that are more difficult } \\
\text { to chew, including fruits and } \\
\text { vegetables. This interven- } \\
\text { tion was useful in helping } \\
\text { denture wearers to move } \\
\text { into action for fruit and } \\
\text { vegetable consumption }\end{array}$ \\
\hline $\begin{array}{l}14 \text { Calfas et al. } \\
(2002)^{40} \\
\text { Experimental } \\
\text { study } \\
\text { Fair rating }\end{array}$ & $\begin{array}{l}\text { Can a computerised } \\
\text { assessment pro- } \\
\text { gramme plus brief } \\
\text { counselling } \\
\text { improve nutrition } \\
\text { and exercise } \\
\text { behaviour among } \\
\text { primary-care } \\
\text { patients? }\end{array}$ & $\begin{array}{l}\text { Adult primary-care } \\
\text { patients ( } n 173 ; \\
\text { forty-five in inter- } \\
\text { vention group 1; } \\
\text { forty-one in inter- } \\
\text { vention group 2; } \\
\text { forty-one in inter- } \\
\text { vention group 3; } \\
\text { forty-six in control } \\
\text { group; } 69 \% \text { female; } \\
71 \% \text { white; average } \\
\text { age } 37 \text { years; } 21 \% \\
(n 49) \text { lost to follow- } \\
\text { up) }\end{array}$ & $\begin{array}{l}\text { PACE }+ \text { is stage-matched. } \\
\text { Computerised assessment is } \\
\text { supplemented by mail and/or } \\
\text { telephone counselling }\end{array}$ & $\begin{array}{l}\text { Baseline and 4-month } \\
\text { post-programme } \\
\text { interviews assessed } \\
\text { the following: stage } \\
\text { of change (for } \\
\text { physical activity } \\
\text { only), overeating } \\
\text { behaviour, block } \\
\text { simplified fat } \\
\text { screener (fat } \\
\text { intake), and fruit and } \\
\text { vegetable intake }\end{array}$ & $\begin{array}{l}\text { Participants improved both } \\
\text { exercise and dietary beha- } \\
\text { viour over the study period. } \\
\text { The more intensive inter- } \\
\text { ventions were not more } \\
\text { effective than the less } \\
\text { intensive one, though }\end{array}$ & $\begin{array}{l}\text { Given that stage of change was } \\
\text { only assessed for exercise } \\
\text { behaviour and only } \\
\text { assessed at baseline, it is } \\
\text { impossible to know the } \\
\text { effect of the intervention on } \\
\text { stage movement }\end{array}$ \\
\hline
\end{tabular}




\begin{tabular}{|c|c|c|c|c|c|c|}
\hline $\begin{array}{l}\text { Study no. and } \\
\text { reference }\end{array}$ & Research question & Sample characteristics & Intervention & Measures & Findings & Implications \\
\hline $\begin{array}{l}15 \text { Clark et al. } \\
(2004)^{41} \\
\text { Experimental } \\
\text { study } \\
\text { Good rating }\end{array}$ & $\begin{array}{l}\text { Do brief, tailored life- } \\
\text { style self-man- } \\
\text { agement interven- } \\
\text { tions improve the } \\
\text { process of lifestyle } \\
\text { behaviour change } \\
\text { for diet and physi- } \\
\text { cal activity with } \\
\text { patients who have } \\
\text { type } 2 \text { diabetes? }\end{array}$ & $\begin{array}{l}\text { Diabetic patients ( } n \\
\text { 100; forty-eight in } \\
\text { intervention group; } \\
\text { forty-six in control } \\
\text { group; retention rate } \\
94 \%)\end{array}$ & $\begin{array}{l}\text { Intervention group received brief } \\
\text { tailored intervention, including } \\
\text { follow-up telephone calls. } \\
\text { Control group received care } \\
\text { as usual }\end{array}$ & $\begin{array}{l}\text { Both questionnaire and } \\
\text { physiological } \\
\text { assessments were } \\
\text { given at baseline, } 3 \\
\text { months and } 1 \text { year. } \\
\text { They assessed } \\
\text { stages of change for } \\
\text { dietary fat } \\
\text { reduction }^{99} \text {, stage of } \\
\text { change for exercise, } \\
\text { self-efficacy and } \\
\text { barriers to change }\end{array}$ & $\begin{array}{l}\text { Participants in the intervention } \\
\text { group perceived themselves } \\
\text { to have changed from con- } \\
\text { templation to action for } \\
\text { dietary fat reduction and } \\
\text { lifestyle physical activity } \\
\text { levels due to decreased } \\
\text { barriers but not increased } \\
\text { self-efficacy. Results pro- } \\
\text { vide further evidence of the } \\
\text { effectiveness of tailored } \\
\text { interventions for lifestyle } \\
\text { change }\end{array}$ & $\begin{array}{l}\text { There is an increase in under- } \\
\text { standing the change pro- } \\
\text { cesses over time for multiple } \\
\text { behaviours, allowing beha- } \\
\text { vioural and preventive medi- } \\
\text { cine to have a more } \\
\text { significant impact when tar- } \\
\text { geting behaviour change in } \\
\text { individuals with multiple risks. } \\
\text { These findings may help in } \\
\text { developing more effective } \\
\text { and efficient interventions }\end{array}$ \\
\hline $\begin{array}{l}16 \text { Cookson et al. } \\
(2000)^{42} \\
\text { Non-exper- } \\
\text { imental study }\end{array}$ & $\begin{array}{l}\text { Can a mailed self- } \\
\text { help intervention } \\
\text { package affect } \\
\text { nutrition beha- } \\
\text { viour changes in } \\
\text { parents and their } \\
\text { children? }\end{array}$ & $\begin{array}{l}\text { Canadian parents of } \\
\text { children aged } 6-12 \\
\text { years ( } n 300 ; 21 \% \\
\text { of initial sample } \\
\text { completed post-pro- } \\
\text { gramme survey) }\end{array}$ & $\begin{array}{l}\text { The HeartSmart Family Fun Pack } \\
\text { is a mailed self-help package } \\
\text { of materials for parents and } \\
\text { children aged } 6-12 \text { years to } \\
\text { promote healthful diets, exer- } \\
\text { cise and non-smoking }\end{array}$ & $\begin{array}{l}\text { Baseline and 3-month } \\
\text { post-programme } \\
\text { written survey } \\
\text { assessed intention } \\
\text { to change (using } \\
\text { three-stage tool } \\
\text { developed by the } \\
\text { authors), dietary } \\
\text { behaviour, exercise } \\
\text { behaviour, and } \\
\text { smoking behaviour }\end{array}$ & $\begin{array}{l}\text { Of parents, } 38 \% \text { said they } \\
\text { improved the diets of their } \\
\text { children; } 28 \% \text { of parents } \\
\text { said they increased the } \\
\text { physical activity of their } \\
\text { children }\end{array}$ & $\begin{array}{l}\text { More than two-thirds of the } \\
\text { parents surveyed indicated } \\
\text { that they had made at least } \\
\text { one positive health-related } \\
\text { change in response to } \\
\text { receiving the intervention. } \\
\text { The lack of comparison group } \\
\text { and small follow-up response } \\
\text { rate limit the conclusions that } \\
\text { may be drawn }\end{array}$ \\
\hline $\begin{array}{l}17 \text { Finckenor et al. } \\
(2000)^{43} \\
\text { Quasi-exper- } \\
\text { imental study } \\
\text { Good rating }\end{array}$ & $\begin{array}{l}\text { Can an intervention } \\
\text { focusing on cogni- } \\
\text { tive processes of } \\
\text { change lead to } \\
\text { dietary changes } \\
\text { among pre-action } \\
\text { staged partici- } \\
\text { pants? }\end{array}$ & $\begin{array}{l}\text { Undergraduate stu- } \\
\text { dents ( } n \text { 110; age } \\
\text { 17-55 years; } 76- \\
83 \% \text { female; } 74- \\
87 \% \text { white; thirty- } \\
\text { eight in intervention } \\
\text { group; thirty in con- } \\
\text { trol group 1; forty- } \\
\text { two in control group } \\
2 \text {; retention rate } 67- \\
68 \% \text { at } 1 \text { year) }\end{array}$ & $\begin{array}{l}\text { Students participated in eleven } \\
15 \text { min sessions offered once } \\
\text { per week. Lessons incorpor- } \\
\text { ated a group-oriented dietary } \\
\text { fat reduction intervention } \\
\text { using the cognitive processes } \\
\text { of change }\end{array}$ & $\begin{array}{l}\text { Baseline, 14-week } \\
\text { post-programme } \\
\text { assessment and } \\
\text { 1-year post-pro- } \\
\text { gramme assess- } \\
\text { ment were } \\
\text { conducted. The } \\
\text { stages-of-change } \\
\text { algorithm for dietary } \\
\text { fat reduction }{ }^{100} \text { and } \\
\text { the eating choices } \\
\text { food questionnaire } \\
\text { were used }\end{array}$ & $\begin{array}{l}\text { Students receiving the inter- } \\
\text { vention showed significant } \\
\text { forward stage progression } \\
\text { that was maintained at } 1 \\
\text { year. Students in the control } \\
\text { group who received pre- and } \\
\text { post-surveys also showed } \\
\text { forward stage progression, } \\
\text { but not for } 1 \text { year }\end{array}$ & $\begin{array}{l}\text { It is noteworthy that intervention } \\
\text { participants maintained diet- } \\
\text { ary changes for } 1 \text { year after } \\
\text { the programme. This may } \\
\text { have been a highly motivated } \\
\text { group, though, as all partici- } \\
\text { pants were enrolled in a } \\
\text { college nutrition course at the } \\
\text { start. Focusing on cognitive } \\
\text { processes of change for pre- } \\
\text { action participants appeared } \\
\text { to be effective }\end{array}$ \\
\hline $\begin{array}{l}18 \text { Frenn et al. } \\
(2003)^{44} \\
\text { Quasi-exper- } \\
\text { imental study } \\
\text { Good rating }\end{array}$ & $\begin{array}{l}\text { Can a school-based } \\
\text { intervention lead } \\
\text { to diet and exer- } \\
\text { cise changes } \\
\text { among middle- } \\
\text { school students? }\end{array}$ & $\begin{array}{l}\text { Low-income middle- } \\
\text { school students ( } n \\
117 ; 52 \% \text { female; } \\
50 \% \text { African-Ameri- } \\
\text { can; sixty in inter- } \\
\text { vention group; fifty- } \\
\text { seven in control } \\
\text { group; } 91 \% \\
\text { response rate) }\end{array}$ & $\begin{array}{l}\text { Students in intervention classes } \\
\text { received four stage-based } \\
\text { classroom lessons. Interven- } \\
\text { tion group students who were } \\
\text { in preparation, action or } \\
\text { maintenance also participated } \\
\text { in four small group sessions. } \\
\text { Students in the control group } \\
\text { did not receive any type of } \\
\text { nutrition intervention }\end{array}$ & $\begin{array}{l}\text { Baseline and post-pro- } \\
\text { gramme surveys } \\
\text { assessed stage of } \\
\text { change (modified } \\
\text { Greene \& Rossi } \\
\text { Scale }{ }^{82} \text { ), self-effi- } \\
\text { cacy, dietary beha- } \\
\text { viour, exercise } \\
\text { behaviour, and ben- } \\
\text { efits and barriers }\end{array}$ & $\begin{array}{l}\text { Intervention students reported } \\
\text { consuming significantly less } \\
\text { dietary fat than did those in } \\
\text { the control group. Among all } \\
\text { students, self-efficacy was } \\
\text { higher for those in later } \\
\text { stages, and dietary fat } \\
\text { intake was lower for those in } \\
\text { later stages }\end{array}$ & $\begin{array}{l}\text { The TTM appears to fit this } \\
\text { population for dietary fat } \\
\text { consumption. A stage- } \\
\text { based intervention to reduce } \\
\text { dietary fat was effective in } \\
\text { helping students progress } \\
\text { forward in stage }\end{array}$ \\
\hline
\end{tabular}




\begin{tabular}{|c|c|c|}
\hline $\begin{array}{l}19 \text { Greene et al. } \\
(2003)^{45} \\
\text { Non-exper- } \\
\text { imental study }\end{array}$ & $\begin{array}{l}\text { Can a home-based } \\
\text { intervention lead } \\
\text { to diet and exer- } \\
\text { cise changes } \\
\text { among obese } \\
\text { adults? }\end{array}$ & $\begin{array}{l}\text { Obese adults referred } \\
\text { to the programme } \\
\text { by a primary phys- } \\
\text { ician ( } n 31 ; 71 \% \\
\text { female; } 100 \% \\
\text { white; average age } \\
45 \text { years). Twenty } \\
\text { participants com- } \\
\text { pleted the pro- } \\
\text { gramme; sixteen } \\
\text { completed final fol- } \\
\text { low-up survey }\end{array}$ \\
\hline $\begin{array}{l}\text { 110 Johnson et al. } \\
(2006)^{46} \\
\text { Experimental } \\
\text { study } \\
\text { Fair rating }\end{array}$ & $\begin{array}{l}\text { Can a computerised } \\
\text { 'expert system' } \\
\text { intervention lead } \\
\text { to forward stage } \\
\text { movement for } \\
\text { dietary fat } \\
\text { reduction among } \\
\text { patients taking } \\
\text { lipid-lowering } \\
\text { medication? }\end{array}$ & $\begin{array}{l}\text { Patients on lipid-lower- } \\
\text { ing medication ( } n \\
404 ; 50 \% \text { male; age } \\
21-85 \text { years; } 202 \text { in } \\
\text { intervention group; } \\
202 \text { in control group; } \\
65 \% \text { response rate } \\
\text { at } 18 \text { months) }\end{array}$ \\
\hline $\begin{array}{l}\text { I11 Jones et al. } \\
(2003)^{47} \\
\text { Experimental } \\
\text { study } \\
\text { Good rating }\end{array}$ & $\begin{array}{l}\text { Does an integrated, } \\
\text { multi-component } \\
\text { intervention pro- } \\
\text { gramme increase } \\
\text { readiness to } \\
\text { change, self-care } \\
\text { and diabetes con- } \\
\text { trol? }\end{array}$ & $\begin{array}{l}\text { Subjects with type } 1 \\
\text { and type } 2 \text { diabetes } \\
\text { ( } n \text { 1029; } 260 \text { in } \\
\text { intervention group 1; } \\
250 \text { in intervention } \\
\text { group 2; } 269 \text { in } \\
\text { control group 1; } 250 \\
\text { in control group 2; } \\
\text { retention rate } 78- \\
81 \%) \text {. Intention to } \\
\text { treat analysis was } \\
\text { performed }\end{array}$ \\
\hline
\end{tabular}

Participants received twelve action-oriented weekly mailings addressing exercise, dietary fat reduction, portion control, fruit and vegetable consumption and behaviour change

Intervention participants completed the Pro-Change Program for Cholesterol

Medication. They interacted with the computer-generated program and received individualised, stage-matched feedback at three time points Control participants received usual care

An expert system was customised to the individual based on stage of change using phone counselling and newsletters provided for 12 months. Control subjects received treatment as usual. This treatment as usual. This included regular medical examinations and gene diabetes education
Baseline, post-programme (3-month) and 6-month followup surveys were used. Data were collected via physical examination and written survey. TTM measures included stage of change for exercise and stage of change for dietary fat reduction ${ }^{82}$

Participants were assessed at baseline, 6 months, 12 months and 18 months post-pro-

gramme for stage of change (unspecified for dietary fat), dietary fat intake and exercise

Baseline, 3, 6, 9 and 12 months for intervention participants. No contact was permitted for the contro group until the end of the 12-month study. Questions on intention to change and current behaviour assessed stage of change (developed and tested as part of this study)
Mean weight loss for participants was $46 \mathrm{~kg}$ at 6 months. Participants also mowed significant improvements in dietary fat reduction, fruit and vegetable consumption, and an increase in aerobic capacity

Intervention participants were more likely than control group participants to move into action or maintenance and remain there for the duration of the study,

regardless of their stage at baseline. Among intervention participants, $21 \%$ were in action or maintenance for dietary fat reduction by the end of the programme

Intervention participants were significantly more likely than those who received usual care to move forward to action for critical diabetes elf-care behaviours. The intervention has the possibility to positively affect the health of diverse populations diagnosed with diabetes who are ready to

change
The findings of this small, preliminary programme valuation demonstrate that eme-based programmes an be practical, low-cost and effective

Interventions that are integrated and multi-component can be effective by helping large groups of patients with diabetes. This time-efficient programme can redirect fforts to diabetes care and education tactics that result in a positive effect on hindering long-term diabetes conditions and lowering healthcare costs 


\begin{tabular}{|c|c|c|c|c|c|c|}
\hline $\begin{array}{l}\text { Study no. and } \\
\text { reference }\end{array}$ & Research question & Sample characteristics & Intervention & Measures & Findings & Implications \\
\hline $\begin{array}{l}\text { 112 Keller et al. } \\
(2000)^{48} \\
\text { Experimental } \\
\text { study } \\
\text { Poor rating }\end{array}$ & $\begin{array}{l}\text { Can training primary- } \\
\text { care physicians in } \\
\text { counselling skills } \\
\text { based on the TTM } \\
\text { lead to motiva- } \\
\text { tional and beha- } \\
\text { vioural changes in } \\
\text { their patients? }\end{array}$ & $\begin{array}{l}\text { German primary-care } \\
\text { patients ( } n \text { 592; } 274 \\
\text { in intervention } \\
\text { group; } 318 \text { in control } \\
\text { group; retention rate } \\
50 \% \text { ) }\end{array}$ & $\begin{array}{l}\text { Physicians in the intervention } \\
\text { group participated in a work- } \\
\text { shop focusing on the TTM and } \\
\text { general counselling strategies } \\
\text { for behaviour modification. } \\
\text { They then provided stage- } \\
\text { based counselling to their } \\
\text { patients, who volunteered to } \\
\text { complete the programme } \\
\text { assessments. Physicians in } \\
\text { the control group did not } \\
\text { receive training or the bro- } \\
\text { chures. They were asked to } \\
\text { continue usual care treatment }\end{array}$ & $\begin{array}{l}\text { Baseline and after } 12 \\
\text { months assess- } \\
\text { ments were con- } \\
\text { ducted. The stages } \\
\text { of change for diet, } \\
\text { exercise, smoking } \\
\text { and stress manage- } \\
\text { ment were deter- } \\
\text { mined through short } \\
\text { staging algor- } \\
\text { ithms }^{101}\end{array}$ & $\begin{array}{l}\text { After } 12 \text { months, patients in the } \\
\text { intervention group did not } \\
\text { show significant movement } \\
\text { through stages of change for } \\
\text { diet, exercise, smoking and } \\
\text { stress management than did } \\
\text { patients with control phys- } \\
\text { icians. There were no } \\
\text { differences between groups } \\
\text { in counselling frequency, } \\
\text { counselling intensity or } \\
\text { patient satisfaction with } \\
\text { counselling }\end{array}$ & $\begin{array}{l}\text { Limitations of this study were } \\
\text { due to the low recruitment } \\
\text { rate and high dropout rate in } \\
\text { the sample size. The need } \\
\text { for improving motivational } \\
\text { counselling skills of primary- } \\
\text { care physicians is due to the } \\
\text { high numbers of patients in } \\
\text { the early stages of change } \\
\text { and minimal improvement } \\
\text { over time. Future research } \\
\text { should focus on ways to } \\
\text { improve the process of } \\
\text { education for physicians on } \\
\text { implementing counselling } \\
\text { strategies in primary-care } \\
\text { settings }\end{array}$ \\
\hline $\begin{array}{l}\text { I13 Mau et al. } \\
(2001)^{49} \\
\text { Quasi-exper- } \\
\text { imental study } \\
\text { Good rating }\end{array}$ & $\begin{array}{l}\text { Does a lifestyle inter- } \\
\text { vention show } \\
\text { greater changes in } \\
\text { TTM measures for } \\
\text { diet and exercise } \\
\text { behaviour than a } \\
\text { standard interven- } \\
\text { tion? }\end{array}$ & $\begin{array}{l}\text { Native Hawaiians with } \\
\text { or at risk for type } 2 \\
\text { diabetes ( } n 147 ; \\
\text { seventy-two in inter- } \\
\text { vention group; sev- } \\
\text { enty-five in control } \\
\text { group; retention rate } \\
90 \% \text { ) }\end{array}$ & $\begin{array}{l}\text { Intervention participants received } \\
\text { a culturally specific pro- } \\
\text { gramme. They were asked to } \\
\text { choose a support person to } \\
\text { attend programme activities } \\
\text { with them and were given } \\
\text { instructions on how to ask his } \\
\text { or her support person for help } \\
\text { in overcoming challenges in } \\
\text { changing lifestyle behaviours. } \\
\text { The control group received a } \\
\text { culturally competent pro- } \\
\text { gramme }\end{array}$ & $\begin{array}{l}\text { A 3-4 } \mathrm{h} \text { research } \\
\text { examination con- } \\
\text { sisting of question- } \\
\text { naires and } \\
\text { interviews were } \\
\text { given on site at } \\
\text { baseline, } 6 \text { months } \\
\text { and at } 1 \text { year to } \\
\text { assess dietary } \\
\text { stages of change for } \\
\text { fat and fibre } \\
\text { intake } \\
\text { of change for exer- } \\
\text { cise }\end{array}$ & $\begin{array}{l}\text { Stage of change for fat and } \\
\text { fibre intake was significantly } \\
\text { associated with positive } \\
\text { dietary and exercise beha- } \\
\text { viours. Participants receiv- } \\
\text { ing support intervention } \\
\text { were more likely to move } \\
\text { forward from pre-action to } \\
\text { action or maintenance and } \\
\text { showed more improvement } \\
\text { in those stages than did the } \\
\text { control group }\end{array}$ & $\begin{array}{l}\text { Support intervention had posi- } \\
\text { tive results in stage } \\
\text { advancement and social } \\
\text { support roles; however, it } \\
\text { was not effective in main- } \\
\text { taining individuals at the } \\
\text { action or maintenance } \\
\text { stage. Encouraging beha- } \\
\text { viour change in individuals } \\
\text { with the help from mediators } \\
\text { may aid in the development } \\
\text { of more effective and effi- } \\
\text { cient interventions }\end{array}$ \\
\hline $\begin{array}{l}114 \text { Prochaska } \\
\text { et al. }(2005)^{50} \\
\text { Experimental } \\
\text { study } \\
\text { Good rating }\end{array}$ & $\begin{array}{l}\text { Can stage-based } \\
\text { expert systems } \\
\text { lead primary-care } \\
\text { patients through } \\
\text { stages of change } \\
\text { for multiple risk } \\
\text { behaviours, } \\
\text { including dietary } \\
\text { fat reduction? }\end{array}$ & $\begin{array}{l}\text { Primary-care patients } \\
\text { from seventy-nine } \\
\text { physician practices } \\
\text { ( } n 5407 ; 69 \% \\
\text { recruitment rate; } \\
2667 \text { in intervention } \\
\text { group; } 2740 \text { in con- } \\
\text { trol group; retention } \\
\text { rate } 75 \%)\end{array}$ & $\begin{array}{l}\text { Stage-based expert systems } \\
\text { were used. The intervention } \\
\text { group was mailed stage- } \\
\text { matched material. The control } \\
\text { group completed stages-of- } \\
\text { change and behavioural out- } \\
\text { comes survey. Follow-up } \\
\text { assessments at } 12 \text { and } 24 \\
\text { months were conducted on } \\
\text { participants in both groups }\end{array}$ & $\begin{array}{l}\text { Baseline, } 6 \text { and } 12 \\
\text { months assessed } \\
\text { stage of change for } \\
\text { dietary fat } \\
\text { reduction } \\
\text { other health beha- } \\
\text { viours }\end{array}$ & $\begin{array}{l}\text { Effects of intervention were } \\
\text { significant for treatment } \\
\text { participants in each of the } \\
\text { four behaviours, with 28.8\% } \\
\text { in action for dietary fat } \\
\text { reduction }\end{array}$ & $\begin{array}{l}\text { Stage-matched expert systems } \\
\text { can have a relatively high } \\
\text { impact on a population with } \\
\text { multiple risk behaviours for } \\
\text { cancer and other chronic } \\
\text { diseases. Further research } \\
\text { is needed to determine if } \\
\text { both efficacy and partici- } \\
\text { pation rates can be } \\
\text { increased by having pri- } \\
\text { mary-care physicians begin } \\
\text { multiple behaviour-change } \\
\text { processes }\end{array}$ \\
\hline
\end{tabular}


Parents of teenagers ( $n \quad$ A stage-based expert system $2460 ; 84 \%$ recruitment rate; 1209 in intervention group; 1251 in contro group; retention rate ranged $65-85 \%$ )

readiness for

change in an at-

risk population for

high-fat diets and

viours?

$\begin{array}{ll}\text { I16 Proper et al. } & \text { Does personalised } \\ (2003)^{52} & \text { feedback on fit- } \\ \text { Experimental } & \text { ness and health } \\ \text { study } & \text { status affect an } \\ \text { Good rating } & \text { individual's sub- } \\ & \text { jective appraisal of } \\ & \text { their stage-of- } \\ & \text { change beha- } \\ & \text { viour? }\end{array}$
131 in intervention group; 168 in contro up; $66 \%$ male; retention rate $95 \%$

viou?

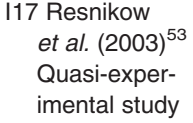

imental study

Fair rating

was used. Stage-matched

self-help manuals for each at-

risk behaviour and progress

questionnaires were mailed to

participants. Phone surveys

were also used to generate

progress reports. The control

group received stages of

change and behaviour out-

comes for the three beha-

viours matched PACE +. PACE assessment forms were completed after testing and again after feedback. The intervention group also had the option of additional measurements for 9 months. The control group received the health and PACE assessment forms were completed before testing and again after testing

Will precontemplators respond differently than preparers to an intervention increase fruit and increase fruit and sumption?

received self-help mate

tailored to pre-action stages. phone call based on motiva-

group 2 receiv

group 2 received four calls.

Control group participants

-tailored nutrition

four churches in
The intervention was the stagefitness test without feedback.
Computer reports were created for each atrisk behaviour at baseline, 6 and 12 months. Stage of change for dietary fat reduction ${ }^{102}$ was assessed

Health and fitness tests were given to both groups at the start of the study. Two

PACE assessment forms were given to both groups. The time interval between completion of the assessments was $1 \mathrm{~h}$. Stage of change was

measured using the stage model for exercise and nutrition (PACE)

Baseline and 1-year surveys included: stage of change ${ }^{8}$, $F F Q$, self-efficacy, barriers to fruit and vegetable intake outcome expectations and portion size knowledge
In 24 months, 34\% of participants reached the action or maintenance stages for

dietary fat reduction. Those in the intervention group were more likely to move forward in stage than the control group

There was no significant change at the behaviour change level for nutrition. There was a significant

change in the intervention group; $12 \%$ reported a relapse on PACE scores for energy intake and weight management, men more so than women. After feedback, $23 \%$ of the intervention group relapsed on their PACE scores of which $53 \%$ moved from action or mainenance to contemplation or preparation

Those in group 1 received on

intervention group 2

control group; $62 \%$

in preparation at

baseline; $21 \%$ in

maintenance at

baseline; retention

rate $85 \%(n 861$ at year))
Participants in pre-contemplation showed the same

degree of change as those tudy outcomes. This was rue for intervention and control group participants. $85 \%$ of precontemplator moved forward at least one stage and $33 \%$ of preparers nterventions that are stagematched expert systems can significantly increase multiple behaviour changes in at-risk populations where the majority of participants are not prepared to change. Further research is needed for this expert system to determine if staged-based multiple behaviour change programmes are effective with different populations

Personalised feedback does not immediately induce a change at the level of

behaviour stage, but can induce changes in PACE scores and realistic appraisal of participants of their stage of change. Giving feedback at baseline on measurements in an intervention study can influence PACE scores and can be considered a small but important gain

This study does not support the application of the stage-ofchange concept to this study population. The authors note that participants may not have been representative of the larger population. They also note that more frequent assessments (i.e. at 3 and 6 months) may have yielded different results 


\begin{tabular}{|c|c|c|c|c|c|c|}
\hline $\begin{array}{l}\text { Study no. and } \\
\text { reference }\end{array}$ & Research question & Sample characteristics & Intervention & Measures & Findings & Implications \\
\hline $\begin{array}{l}\text { I18 Riebe et al. } \\
\text { 2005) } \\
\text { Non-exper- } \\
\text { imental study }\end{array}$ & $\begin{array}{l}\text { Can a clinic-based } \\
\text { intervention to } \\
\text { improve diet and } \\
\text { exercise habits } \\
\text { lead to long-term } \\
\text { changes in body } \\
\text { weight and life- } \\
\text { style habits } \\
\text { among partici- } \\
\text { pants? }\end{array}$ & $\begin{array}{l}\text { Moderately overweight } \\
\text { adults ( } n 144 ; 78 \% \\
\text { female; } 97 \% \text { Cau- } \\
\text { casian; average age } \\
50 \text { years; retention } \\
\text { rate } 76 \%)\end{array}$ & $\begin{array}{l}\text { Stage-matched intervention } \\
\text { focused on lifestyle change } \\
\text { and not weight loss specifi- } \\
\text { cally. Initially met twice per } \\
\text { week for exercise and lifestyle } \\
\text { counselling; gradually tapered } \\
\text { to fewer meetings }\end{array}$ & $\begin{array}{l}\text { 6-month and 24-month } \\
\text { post-intervention } \\
\text { assessments } \\
\text { included BMI, self- } \\
\text { reported dietary } \\
\text { intake and exercise, } \\
\text { and TTM processes } \\
\text { of change. (Note: } \\
\text { this is a follow-up } \\
\text { analysis of the } \\
\text { Riebe et al. }{ }^{55} \text { study } \\
\text { also reported in this } \\
\text { table as study I19) }\end{array}$ & $\begin{array}{l}\text { Regular exercise and mainten- } \\
\text { ance of a healthy diet were } \\
\text { associated with greater use } \\
\text { of processes of change. } \\
\text { Exercise was also associ- } \\
\text { ated with higher confidence. } \\
\text { Healthy diet was also } \\
\text { associated with lower temp- } \\
\text { tation scores }\end{array}$ & $\begin{array}{l}\text { This study lends evidence of } \\
\text { the long-term benefits of an } \\
\text { intensive, stage-based } \\
\text { intervention aimed at per- } \\
\text { manent lifestyle change and } \\
\text { not simply weight loss. It } \\
\text { supports the use of a stage- } \\
\text { based intervention }\end{array}$ \\
\hline $\begin{array}{l}\text { I19 Riebe et al. } \\
\qquad(2003)^{55} \\
\text { Non-exper- } \\
\text { imental study }\end{array}$ & $\begin{array}{l}\text { Can an intensive, } \\
\text { stage-based } \\
\text { weight-loss inter- } \\
\text { vention based on } \\
\text { diet, exercise and } \\
\text { behaviour modifi- } \\
\text { cation lead to } \\
\text { positive health } \\
\text { changes? }\end{array}$ & $\begin{array}{l}\text { Moderately overweight } \\
\text { adults ( } n 144 ; 78 \% \\
\text { female; } 97 \% \text { Cau- } \\
\text { casian; average age } \\
50 \text { years; retention } \\
\text { rate } 76 \%)\end{array}$ & $\begin{array}{l}\text { Stage-matched intervention } \\
\text { focused on lifestyle change } \\
\text { and not weight loss specifi- } \\
\text { cally. Initially met twice per } \\
\text { week for exercise and lifestyle } \\
\text { counselling; gradually tapered } \\
\text { to fewer meetings }\end{array}$ & $\begin{array}{l}\text { Baseline, 3-month and } \\
\text { 6-month assess- } \\
\text { ments included BMI, } \\
\text { lipid profile, exercise } \\
\text { testing, assessment } \\
\text { of dietary logs. } \\
\text { Baseline-only } \\
\text { assessment of TTM } \\
\text { measures for exer- } \\
\text { cise and dietary fat } \\
\text { intake }\end{array}$ & $\begin{array}{l}\text { Most subjects were within } \\
\text { recommended levels at } \\
\text { baseline for dietary fat and } \\
\text { fruit and vegetable intake, } \\
\text { but were not meeting exer- } \\
\text { cise guidelines. At } 6 \text { months, } \\
\text { LDL-cholesterol and energy } \\
\text { intake decreased, and } \\
\text { aerobic fitness increased }\end{array}$ & $\begin{array}{l}\text { Although intervention was } \\
\text { stage-based, stage tran- } \\
\text { sitions and use of processes } \\
\text { of change were not } \\
\text { measured }\end{array}$ \\
\hline $\begin{array}{l}\text { I20 Soweid et al. } \\
(2003)^{56} \\
\text { Non-exper- } \\
\text { imental study }\end{array}$ & $\begin{array}{l}\text { Can a health-aware- } \\
\text { ness course } \\
\text { change health- } \\
\text { related attitudes } \\
\text { and self-reported } \\
\text { behaviours, } \\
\text { including fruit and } \\
\text { vegetable intake, } \\
\text { of undergraduate } \\
\text { students enrolled } \\
\text { in the class? }\end{array}$ & $\begin{array}{l}\text { Undergraduate stu- } \\
\text { dents }(n 32 ; \text { reten- } \\
\text { tion rate } 50 \%)\end{array}$ & $\begin{array}{l}\text { The intervention was an under- } \\
\text { graduate health awareness } \\
\text { course taken by college } \\
\text { juniors and seniors of various } \\
\text { majors }\end{array}$ & $\begin{array}{l}\text { The comprehensive } \\
\text { health assessment } \\
\text { inventory was used } \\
\text { to assess attitude } \\
\text { and self-report } \\
\text { behaviour of stu- } \\
\text { dents }\end{array}$ & $\begin{array}{l}\text { Results showed improvement } \\
\text { of at least } 20 \% \text { from pretest } \\
\text { score in four out of eleven } \\
\text { health topics and } 10-20 \% \\
\text { in additional five topical } \\
\text { areas. Forward stage } \\
\text { movement was seen for } \\
\text { several behaviours, includ- } \\
\text { ing fruit and vegetable } \\
\text { intake }\end{array}$ & $\begin{array}{l}\text { The study indicated support for } \\
\text { the impact of a health- } \\
\text { awareness class on knowl- } \\
\text { edge, attitude and behaviour } \\
\text { of undergraduate students. } \\
\text { Future research should } \\
\text { include a large sample size } \\
\text { and control group }\end{array}$ \\
\hline $\begin{array}{l}\text { I21 Steptoe et al. } \\
(2003)^{57} \\
\text { Experimental } \\
\text { study } \\
\text { Good rating }\end{array}$ & $\begin{array}{l}\text { Can a brief physician- } \\
\text { delivered inter- } \\
\text { vention improve } \\
\text { fruit and vegetable } \\
\text { consumption } \\
\text { among patients? }\end{array}$ & $\begin{array}{l}\text { Primary-care adult } \\
\text { patients from a low- } \\
\text { income, inner-city } \\
\text { area in the UK ( } n \\
271 ; 61 \% \text { female; } \\
\text { average age } 43 \\
\text { years; } 136 \text { in inter- } \\
\text { vention group; } 135 \\
\text { in control group; } \\
81 \% \text { response rate } \\
\text { at } 12 \text { months) }\end{array}$ & $\begin{array}{l}\text { Intervention participants received } \\
\text { two } 15 \text { min, stage-based } \\
\text { nurse-delivered counselling } \\
\text { sessions during office visits. } \\
\text { Control participants received } \\
\text { general nutrition counselling } \\
\text { during two office visits }\end{array}$ & $\begin{array}{l}\text { Baseline and 12-month } \\
\text { self-reported num- } \\
\text { ber of vegetables } \\
\text { and fruits eaten } \\
\text { daily; biochemical } \\
\text { measures of nutri- } \\
\text { ents found in urina- } \\
\text { lysis, and stage of } \\
\text { change (algorithm } \\
\text { developed by } \\
\text { authors) were } \\
\text { assessed }\end{array}$ & $\begin{array}{l}\text { Patients receiving stage-based } \\
\text { counselling reported higher } \\
\text { intakes of fruit and veg- } \\
\text { etables than did patients in } \\
\text { the control group }\end{array}$ & $\begin{array}{l}\text { While the generic nutrition } \\
\text { counselling was also effec- } \\
\text { tive in promoting change, } \\
\text { the stage-specific counsel- } \\
\text { ling promoted greater } \\
\text { increases in fruit and veg- } \\
\text { etable consumption }\end{array}$ \\
\hline
\end{tabular}




\begin{tabular}{|c|c|c|}
\hline $\begin{array}{l}\text { I22 Steptoe et al. } \\
(2001)^{58} \\
\text { Experimental } \\
\text { study } \\
\text { Fair rating }\end{array}$ & $\begin{array}{l}\text { Can a brief, phys- } \\
\text { ician-delivered } \\
\text { intervention lead } \\
\text { to positive } \\
\text { changes in dietary } \\
\text { fat intake, exer- } \\
\text { cise and smoking } \\
\text { behaviour among } \\
\text { patients at risk for } \\
\text { heart disease? }\end{array}$ & $\begin{array}{l}\text { Primary-care patients } \\
\text { in the UK from } \\
\text { twenty physician } \\
\text { practices ( } n 883 ; \\
316 \text { in intervention } \\
\text { group; } 567 \text { in control } \\
\text { group; } 96 \% \text { white; } \\
54 \% \text { female; } 79 \% \\
\text { elevated BMl; } \\
\text { retention rate } 54- \\
62 \%)\end{array}$ \\
\hline $\begin{array}{l}\text { I23 Taylor et al. } \\
(2000)^{59} \\
\text { Non-exper- } \\
\text { imental study }\end{array}$ & $\begin{array}{l}\text { Can a culturally sen- } \\
\text { sitive, stage- } \\
\text { based programme } \\
\text { for low-income } \\
\text { Hispanic mothers } \\
\text { lead to changes in } \\
\text { dietary knowl- } \\
\text { edge, attitudes } \\
\text { and behaviours? }\end{array}$ & $\begin{array}{l}\text { Hispanic mothers, low- } \\
\text { income and/or } \\
\text { migrant farm } \\
\text { workers ( } n 337 ; \\
\text { response rate } 24 \% \\
\text { at 6-month follow- } \\
\text { up) }\end{array}$ \\
\hline $\begin{array}{l}124 \text { Van Der Veen } \\
\text { et al. }(2002)^{60} \\
\text { Experimental } \\
\text { study } \\
\text { Good rating }\end{array}$ & $\begin{array}{l}\text { Does stage-matched } \\
\text { nutrition counsel- } \\
\text { ling by family } \\
\text { physicians have } \\
\text { an effect on diet- } \\
\text { ary fat intake and } \\
\text { serum lipid levels? }\end{array}$ & $\begin{array}{l}\text { Dutch primary-care } \\
\text { patients at risk for } \\
\text { heart disease ( } n \\
\text { 143; seventy-one in } \\
\text { intervention group; } \\
\text { seventy-two in con- } \\
\text { trol group; retention } \\
\text { rate } 90 \%)\end{array}$ \\
\hline
\end{tabular}

The Change of Heart Program is a stage-based intervention delivered by trained nurses during patient examinations. Intervention participants received two to three counselling sessions beyond the initial physician visit. Control participants received non-tailored advice during the physician visit only

Stage-based, community intervention trained the grandmothers to deliver a face-toface intervention to mothers of young children in five educational meetings

The intervention group received TTM-based nutrition counselling by family physicians with selective referral to a dietitian. The control group received care as usual
Baseline, 4-month and 12-month assessments of: stage of change $^{3}, F F Q$, and the UK National Fitness Survey

mmediate and 6month post-programme surveys measured: stage of change (algorithm not specified) for seven specific dietseven specilic diet$\mathrm{Na}$, sugar, and $\mathrm{Na}$, sugar, and
label-reading); nutrilabel-reading); nutri-
tion knowledge, attitudes and behaviour

At baseline, 6 and 12 months patients

were presented with a self-administered questionnaire on demographics medical history and food frequency ${ }^{103}$. A four-item algorithm ${ }^{104}$ assessed stages of change for reduction of fat intake
Intervention participants were significantly more likely than control participants to

advance to action or maintenance at both assessment times; however, control participants also showed forward stage progression at

both assessments. The

intervention was most effective for those in precontemplation or contemplation

For all of the nutrition behaviours assessed, most subjects were in either

preparation or maintenance

at baseline, post-pro-

gramme and follow-up assessments. While knowl edge and attitudes

appeared to increase,

behaviour was more difficult to assess

Total fat and saturated fat intake at 6 months decreased significantly more in the intervention group $(-5.7 \%)$ than the control group (-2.6\%); at 12 months being decreased more in the intervention group $(-3.6 \%)$ than the control group $(-1.7 \%)$.

There were only significant differences in body weight 6 months and no significan changes in serum lipids at 12 months between the two groups
Stage-matched primary-care counselling of patients at sk for high-fat diets is supported by this study, particularly for patients who are in pre-contemplation and contemplation. Those in preparation or action did not appear to significantly benefit from the intervention

There appear to be significan cultural and educational barriers to applying the stage-of-change construct to this population. Despite the use of appropriate, welltrained peer educators, many participants did not want to be tested or measured and may have given 'desirable', rather than accurate, responses

This intervention led to the reduction in short- and longterm dietary fat intake and short-term weight loss among patients receiving the counselling. Emphasis on future research should be testing new methods to maintain dietary behaviour changes, particularly among low socio-economic status patients 


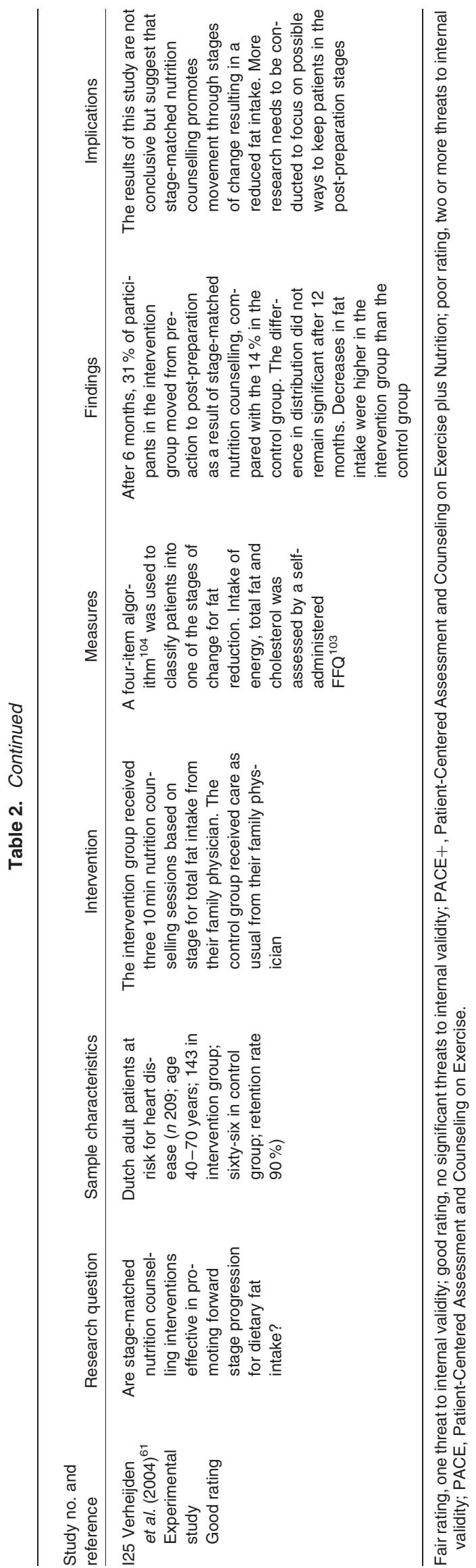

studies assessed portion control, two studies assessed fibre intake, and one study assessed both $\mathrm{Na}$ intake and sugar intake. None had weight loss as a primary study goal or programme focus.

Sixteen studies used staging algorithms that had been previously validated for use with a specific nutrition behaviour. In two studies, authors adapted the tobacco staging algorithm. In three other studies, the staging algorithm used was either unspecified or described in terms too general to determine the specific algorithm used. Finally, one study used a non-validated algorithm developed by the authors of that study.

Of the twenty-five studies, nineteen supported the use of stage-based dietary interventions. These included twelve studies with experimental designs (study numbers I2, I3, I5, I10, I11, I14-16, I21, I22, I24 and I25), three studies with quasi-experimental designs (study numbers I7, I8 and I13) and four programme evaluations using non-experimental designs (study numbers I6, I9, I18 and I23). These studies included populations of primary-care patients, patients at risk for heart disease, patients on cholesterol-lowering drugs, type 2 diabetics, denture-wearers, parents, Canadian adults, English adults, Dutch adults, native Hawaiians, two of the four low-income populations, and students.

Two studies clearly did not support the use of stage-based dietary interventions. One of these was a well-designed, quasi-experimental study of African-American church members, many of whom were low income (study number I17). In this study, participants in precontemplation performed as well as those in preparation in terms of changing and maintaining healthful dietary habits. The second study was a non-experimental programme evaluation of a dietary intervention designed for and delivered to mothers in migrant farm working families (study number I23). The authors identified several significant barriers to reaching this population and concluded that the method of evaluation of stage of change for this population needs to be culturally sensitive and specific to them. In another study (number I1), it was unclear whether the intervention was stage-matched or not, as each participant designed his or her own intervention, and the interventions were not reviewed by the researchers. Among native Hawaiians, the stagematched intervention was effective in promoting stage progression in earlier stages, but not in enabling those in later stages to maintain their changes (study number I13). While Keller et $_{\text {al. }}{ }^{48}$ (study number I12) did not find support for the use of TTM-based counselling among physicians with their patients, it is important to note that the study suffered from several flaws, including low recruitment and retention rates. The final two studies (study numbers I4 and I18) did not provide follow-up measures of TTM constructs; however, a follow-up study of the Riebe et al. ${ }^{55}$ (study number I19) sample demonstrated support for the TTM.

Compared with the three intervention studies included in the Horwath ${ }^{4}$ literature review, the twenty-five intervention studies in the present paper add considerable evidence to support the effectiveness of stage-based interventions for dietary behaviour. Of the three interventions included in the Horwath review, only one was stage-matched, meaning that the intervention was tailored to the stage of each participant. In the present study, nineteen were stage-matched, including 
Table 3. Summary of validation studies of the transtheoretical model (TTM) as applied to dietary behaviour

\begin{tabular}{|c|c|c|c|c|c|c|}
\hline $\begin{array}{l}\text { Study no. and } \\
\text { reference }\end{array}$ & Research purpose & $\begin{array}{c}\text { Sample } \\
\text { characteristics }\end{array}$ & $\begin{array}{l}\text { Study design } \\
\text { and measures }\end{array}$ & Type of analysis & Findings & Implications \\
\hline $\begin{array}{l}\text { V1 De Oliviera et al. } \\
(2005)^{62} \\
\text { Descriptive study }\end{array}$ & $\begin{array}{l}\text { Create and validate a } \\
\text { measure for asses- } \\
\text { sing processes of } \\
\text { change for fruit and } \\
\text { vegetable consump- } \\
\text { tion }\end{array}$ & $\begin{array}{l}\text { Volunteer sample of } \\
250 \text { male college } \\
\text { students: white } \\
\text { American ( } n \text { 105); } \\
\text { Latino ( } n \text { 53); Asian } \\
\text { ( } n \text { 92) }\end{array}$ & $\begin{array}{l}\text { Cross-sectional, written } \\
\text { survey assessed: pro- } \\
\text { cesses of change (cre- } \\
\text { ated in this study), stage } \\
\text { of change }{ }^{105} \text {, fruit } \\
\text { intake, and vegetable } \\
\text { intake }\end{array}$ & $\begin{array}{l}\text { Principal-components } \\
\text { analysis, analysis of } \\
\text { covariance, two-way } \\
\text { ANOVA and } x^{2} \text { analysis } \\
\text { were used }\end{array}$ & $\begin{array}{l}\text { The authors created a valid and } \\
\text { reliable processes-of- } \\
\text { change survey instrument. } \\
\text { Participants differed in their } \\
\text { use of processes based on } \\
\text { culture, with Asians using } \\
\text { more processes than the } \\
\text { other two groups. All par- } \\
\text { ticipants used more cogni- } \\
\text { tive processes than } \\
\text { behavioural ones. Those in } \\
\text { pre-action stages used } \\
\text { fewer processes }\end{array}$ & $\begin{array}{l}\text { Participants in pre-action } \\
\text { stages used fewer pro- } \\
\text { cesses than those in } \\
\text { preparation, action or } \\
\text { maintenance, as pre- } \\
\text { dicted by the TTM. The } \\
\text { use of cognitive pro- } \\
\text { cesses in lieu of beha- } \\
\text { vioural ones is not } \\
\text { predicted by the TTM. } \\
\text { TTM-based interven- } \\
\text { tions should be culturally } \\
\text { specific }\end{array}$ \\
\hline $\begin{array}{l}\text { V2 De Vet et al. } \\
\begin{array}{l}(2005)^{63} \\
\text { Multiple time } \\
\text { series study }\end{array}\end{array}$ & $\begin{array}{l}\text { Determine if stage of } \\
\text { change, decisional } \\
\text { balance and self- } \\
\text { efficacy change in } \\
\text { expected directions } \\
\text { between precon- } \\
\text { templation and con- } \\
\text { templation for fruit } \\
\text { intake }\end{array}$ & $\begin{array}{l}\text { Random sample of } 735 \\
\text { Dutch adults in pre- } \\
\text { contemplation for } \\
\text { fruit consumption } \\
\text { (51\% female; } \\
\text { response rate was } \\
78 \% \text { at time } 3 \text { ) }\end{array}$ & $\begin{array}{l}\text { Longitudinal, internet- } \\
\text { based survey assessed: } \\
\text { stage of change }{ }^{106}, \\
\text { decisional balance, self- } \\
\text { efficacy, and fruit intake. } \\
\text { Measures assessed at } \\
\text { baseline, } 53 \mathrm{~d} \text { and } 106 \mathrm{~d}\end{array}$ & $\begin{array}{l}\text { Logistic regression was } \\
\text { used; compared longi- } \\
\text { tudinal and cross-sec- } \\
\text { tional analysis of data }\end{array}$ & $\begin{array}{l}\text { Pros predicted forward stage } \\
\text { progression from both pre- } \\
\text { contemplation and contem- } \\
\text { plation; cons predicted } \\
\text { neither. Self-efficacy pre- } \\
\text { dicted forward stage move- } \\
\text { ment from } \\
\text { precontemplation. Fruit } \\
\text { intake increased from pre- } \\
\text { contemplation to contem- } \\
\text { plation }\end{array}$ & $\begin{array}{l}\text { The TTM appears to accu- } \\
\text { rately predict increases } \\
\text { in fruit intake in early } \\
\text { stages }\end{array}$ \\
\hline $\begin{array}{l}\text { V3 De Vet et al. } \\
\text { 2005) } \\
\text { Multiple time } \\
\text { series study }\end{array}$ & $\begin{array}{l}\text { Predictability and stab- } \\
\text { ility of stage of } \\
\text { change for fruit } \\
\text { intake across all } \\
\text { stages }\end{array}$ & $\begin{array}{l}\text { Random sample of } 735 \\
\text { Dutch adults (51\% } \\
\text { female; average age } \\
37 \text { years; } 61 \% \\
\text { response rate) }\end{array}$ & $\begin{array}{l}\text { Longitudinal, internet- } \\
\text { based surveys } \\
\text { assessed measures six } \\
\text { times over } 4 \text { months } \\
\text { using the following } \\
\text { assessments: stage of } \\
\text { change }^{81} \text { and fruit intake }\end{array}$ & $\begin{array}{l}\text { MANOVA for repeated } \\
\text { measures and one-way } \\
\text { ANOVA were used }\end{array}$ & $\begin{array}{l}\text { Precontemplation and main- } \\
\text { tenance were the most } \\
\text { stable stages; preparation } \\
\text { was least stable. Stage } \\
\text { stability was higher for } \\
\text { shorter time durations than } \\
\text { for longer ones. Subjects } \\
\text { moved through the stages in } \\
\text { a sequential, predictable } \\
\text { pattern in most cases }\end{array}$ & $\begin{array}{l}\text { Stage of change appears to } \\
\text { be predictable and } \\
\text { stable as adults move } \\
\text { through the stages of } \\
\text { fruit intake, although } \\
\text { there was some varia- } \\
\text { bility in the patterns. In a } \\
\text { small number of cases, } \\
\text { participants reported } \\
\text { moving through stages } \\
\text { in theoretically imposs- } \\
\text { ible patterns, raising } \\
\text { questions about the } \\
\text { accuracy of staging for } \\
\text { fruit intake }\end{array}$ \\
\hline
\end{tabular}




\begin{tabular}{|c|c|c|c|c|c|c|}
\hline $\begin{array}{l}\text { Study no. and } \\
\text { reference }\end{array}$ & Research purpose & $\begin{array}{c}\text { Sample } \\
\text { characteristics }\end{array}$ & $\begin{array}{l}\text { Study design } \\
\text { and measures }\end{array}$ & Type of analysis & Findings & Implications \\
\hline $\begin{array}{l}\text { V4 Di Noia et al. } \\
\quad(2006)^{65} \\
\text { Descriptive study }\end{array}$ & $\begin{array}{l}\text { Develop scales for } \\
\text { measuring pro- } \\
\text { cesses of change, } \\
\text { decisional balance } \\
\text { and self-efficacy for } \\
\text { fruit and vegetable } \\
\text { consumption }\end{array}$ & $\begin{array}{l}\text { Volunteer sample of } \\
319 \text { low-income } \\
\text { African-American } \\
\text { adolescents in New } \\
\text { York City (age range } \\
11-14 \text { years; } 65 \% \\
\text { female; fifty-seven } \\
\text { served in focus } \\
\text { groups and pilot } \\
\text { testing; } 262 \text { com- } \\
\text { pleted the survey) }\end{array}$ & $\begin{array}{l}\text { Initially, a smaller focus } \\
\text { group was used to gen- } \\
\text { erate items and develop } \\
\text { the scales. The larger } \\
\text { group was then used to } \\
\text { test the scales via a } \\
\text { written survey. } \\
\text { Measures included: } \\
\text { stage of change }{ }^{105} \text {, } \\
\text { decisional balance, self- } \\
\text { efficacy and the pro- } \\
\text { cesses of change }\end{array}$ & $\begin{array}{l}\text { Principal-components } \\
\text { analysis, ANOVA and } t \\
\text { tests were used to ana- } \\
\text { lyse the data }\end{array}$ & $\begin{array}{l}\text { Adolescents who were in action } \\
\text { or maintenance had lower } \\
\text { cons and higher pros than } \\
\text { did those in pre-action } \\
\text { stages. They also used the } \\
\text { processes of change more } \\
\text { frequently. There was no } \\
\text { differentiation between the } \\
\text { use of cognitive and beha- } \\
\text { vioural processes of } \\
\text { change, though }\end{array}$ & $\begin{array}{l}\text { TTM-based interventions } \\
\text { for this population seem } \\
\text { to be warranted. It is not } \\
\text { clear from these results, } \\
\text { though, which pro- } \\
\text { cesses would be most } \\
\text { useful for each stage. } \\
\text { This is one of the first } \\
\text { applications of a TTM- } \\
\text { based fruit and veg- } \\
\text { etable intervention with } \\
\text { this population }\end{array}$ \\
\hline $\begin{array}{l}\text { V5 Hargreaves et al. } \\
(1999)^{66} \\
\text { Descriptive studies }\end{array}$ & $\begin{array}{l}\text { Create a stage-of- } \\
\text { change algorithm for } \\
\text { assessing dietary fat } \\
\text { intake }\end{array}$ & $\begin{array}{l}\text { Two volunteer samples } \\
\text { of } 174 \text { adult African- } \\
\text { American females } \\
\text { (average age } 44 \\
\text { years) and } 208 \text { adult } \\
\text { African-American } \\
\text { females (average age } \\
40 \text { years); response } \\
\text { rates not given }\end{array}$ & $\begin{array}{l}\text { Two separate studies were } \\
\text { conducted, measuring } \\
\text { stage of change (cre- } \\
\text { ated for this study), } \\
\text { dietary fat intake, and } \\
\text { dietary fibre intake }\end{array}$ & $\begin{array}{l}\text { MANOVA, ANOVA, Pear- } \\
\text { son's correlation and } \\
\text { hierarchical cluster } \\
\text { analysis were used }\end{array}$ & $\begin{array}{l}\text { Authors used data from study } 1 \\
\text { to develop the eating styles } \\
\text { questionnaire, which } \\
\text { appeared to accurately } \\
\text { place study } 2 \text { subjects into } \\
\text { different stages }\end{array}$ & $\begin{array}{l}\text { The eating styles question- } \\
\text { naire is useful for sta- } \\
\text { ging African-American } \\
\text { women according to } \\
\text { dietary fat intake }\end{array}$ \\
\hline $\begin{array}{l}\text { V6 Jordan et al. } \\
(2003)^{67} \\
\text { Descriptive study }\end{array}$ & $\begin{array}{l}\text { Create a stage-of- } \\
\text { change algorithm to } \\
\text { assess recovery } \\
\text { from anorexia ner- } \\
\text { vosa }\end{array}$ & $\begin{array}{l}\text { Volunteer sample of } \\
278 \text { individuals in } \\
\text { treatment for anor- } \\
\text { exia nervosa ( } 70 \% \\
\text { response rate) }\end{array}$ & $\begin{array}{l}\text { Cross-sectional survey } \\
\text { measured the following: } \\
\text { readiness to change } \\
\text { (i.e. stage of change), } \\
\text { pros and cons (decisio- } \\
\text { nal balance), visual } \\
\text { analogue recovery } \\
\text { scale, and EAT-26 }\end{array}$ & $\begin{array}{l}\text { MANOVA, ANOVA, and } \\
\text { discriminant function } \\
\text { analysis were used }\end{array}$ & $\begin{array}{l}\text { An algorithm that differentiated } \\
\text { stages according to the } \\
\text { subjects' readiness to stop } \\
\text { bingeing and purging and to } \\
\text { stop restricting foods } \\
\text { appeared to accurately } \\
\text { place subjects into correct } \\
\text { stages }\end{array}$ & $\begin{array}{l}\text { This algorithm can be use- } \\
\text { ful for practitioners as } \\
\text { they work with anorexic } \\
\text { patients to achieve } \\
\text { recovery. It can help } \\
\text { them better understand, } \\
\text { and therefore more } \\
\text { effectively treat, these } \\
\text { patients }\end{array}$ \\
\hline $\begin{array}{l}\text { V7 Kasila et al. } \\
\text { (2003) } \\
\text { Descriptive study }\end{array}$ & $\begin{array}{l}\text { Can stage distribution } \\
\text { of patients with type } \\
2 \text { diabetes or } \\
\text { impaired glucose } \\
\text { tolerance regarding } \\
\text { a variety of dietary } \\
\text { behaviours be } \\
\text { determined through } \\
\text { open-ended dialo- } \\
\text { gue during a coun- } \\
\text { selling session? }\end{array}$ & $\begin{array}{l}\text { Volunteer sample of } \\
\text { sixteen Finnish } \\
\text { patients recently } \\
\text { diagnosed with type } \\
2 \text { diabetes or } \\
\text { impaired glucose } \\
\text { tolerance (sex not } \\
\text { reported; all who } \\
\text { were eligible partici- } \\
\text { pated) }\end{array}$ & $\begin{array}{l}\text { Two trained nurses con- } \\
\text { ducted two interviews } \\
\text { each with sixteen } \\
\text { patients. Deductive } \\
\text { content analysis was } \\
\text { used to analyse the } \\
\text { thirty-two recorded } \\
\text { counselling sessions }\end{array}$ & $\begin{array}{l}\text { A non-validated rubric for } \\
\text { analysis of counselling } \\
\text { conversations was used }\end{array}$ & $\begin{array}{l}\text { Readiness to change was } \\
\text { variable among dietary } \\
\text { behaviours assessed and } \\
\text { was difficult to measure. } \\
\text { Frequently, patients were in } \\
\text { different stages for different } \\
\text { dietary behaviours }\end{array}$ & $\begin{array}{l}\text { Application of the TTM } \\
\text { through counselling } \\
\text { conversations is incon- } \\
\text { sistent, although the } \\
\text { authors believe that it } \\
\text { holds promise for effec- } \\
\text { tive counselling by } \\
\text { nurses }\end{array}$ \\
\hline $\begin{array}{l}\text { V8 Lamb et al. } \\
\quad(2004)^{69} \\
\quad \text { Descriptive study }\end{array}$ & $\begin{array}{l}\text { Comparison of a pre- } \\
\text { viously published } \\
\text { staging algorithm to } \\
\text { a new algorithm to } \\
\text { more accurately } \\
\text { stage individuals for } \\
\text { dietary fat intake }\end{array}$ & $\begin{array}{l}\text { Volunteer sample of } \\
375 \text { employed } \\
\text { adults in the UK } \\
\text { (100\% white; } 64 \% \\
\text { male; average age } \\
37 \text { years; } 57 \% \\
\text { response rate) }\end{array}$ & $\begin{array}{l}\text { Cross-sectional survey } \\
\text { used the following } \\
\text { measures: stage of } \\
\left.\text { change (Curry et al. }{ }^{104}\right) \text {, } \\
\text { stage of change (Lamb } \\
\text { et al. } .^{99} \text { ) and } 24 \mathrm{~h} \text { dietary } \\
\text { recall }\end{array}$ & ANOVA and $\chi^{2}$ were used & $\begin{array}{l}\text { The staging algorithm created } \\
\text { in this study placed more } \\
\text { subjects in pre-action } \\
\text { stages }\end{array}$ & $\begin{array}{l}\text { The staging algorithm in } \\
\text { this study appears to } \\
\text { correct for deficiencies } \\
\text { in the standard algor- } \\
\text { ithm by more specifically } \\
\text { defining preparation as } \\
\text { an 'inconsistently active' } \\
\text { stage rather than an } \\
\text { 'inactive' stage }\end{array}$ \\
\hline
\end{tabular}




$\begin{array}{lr}\text { V9 Ling \& Horwath } & \text { Create and validate a } \\ (2001)^{70} & \text { decisional-balance } \\ \text { Descriptive study } & \text { scale for fruit and } \\ & \text { vegetable intake }\end{array}$

V10 Ling \& Horwath $(2000)^{7}$

Descriptive study

V11 Logue et al.
$(2004)^{72}$
Multiple time
series study

V12 Ma et al.

$(2002)^{73}$

Descriptive study

V13 Ma et al.

$(2001)^{74}$

Descriptive study

Is stage classification more accurate with use of an objective assessment of dietary behaviour? tor dietary ar xhibit more we spend more time in pre-action stages stage of change, decisional balance and self-efficacy in describing fruit and
vegetable intake ithm for fruit and vegetable intake
Random sample of 796 Chinese adults (52\% female; average age 39 years using both mail and elephone assessed stage of change ${ }^{3}$, decisional balance, fruit intake and vegetable intake

lunteer sample of

poreans $(51 \%$ ma-

poreans $(51 \%$ ma

mean age 38.7

years; participation

rate reported els

where)

Random sample of 329 overweight adults in a primary-care setting (28\% AfricanAmerican; age 4069 years; $89 \%$ retention rate) loss than those who

Examine the validity of

Random sample of

1545 young adults $61 \%$ female; $90 \%$ white; $55 \%$ response rate)

Create a staging algor-

Researchers tested the designed to classify individuals by stage of change for dietary goals

Measures were taken at baseline and at 6, 12, 18 and 24 months. They included stage of

change (unspecified), dietary fat intake, fruit and vegetable intake, exercise and body weight

Cross-sectional design employed an initial telephone interview, followed by mailed survey. It assessed stage of change $^{81}$, decisional balance, self-efficacy, fruit intake, and vegetable intake

\section{Volunteer sample Cross-sectional, mailed}

survey measured stage of change ${ }^{82}$, fruit intake

(used quota
Principal-components analysis, factor analysis and ANOVA were used and vegetable intake

Validated, sixteen-item

Ordinal logistic regression

cedures) of 30
Forward stage movement pre-

young adults $(61 \%$

female; $74 \%$ white

$70 \%$ response rate) views for stage assessment (developed for this study) and three $24 \mathrm{~h}$ diet recalls were used analysis and $x^{2}$ were used to analyse the data

Grains, and fruits and vegetable servings increased variably across stage distribution. Stages of change explained 41 and $50 \%$ of the variance in mean number of grains and total fruits and vegetable servings, respectively. Validity measures were adequate

There was a direct positive relationship between spending more time in action or maintenance and increased weight loss. Of the behaviours studied controlling portion sizes had the largest effect on weight loss

Principal-components analysis, cluster analsis and ANOVA were used

elf-efficacy and fruit and vegetable intake increased in a linear pattern from precontemplation to maintenance. Pros increased and cons decreased across the five stages in a predictable manner

ANOVA, Pearson's correlation, factor analysis and cluster analysis were used

Three distinct stages emerged: precontemplation, preparation and maintenance. dicted a large increase in pros and a smaller decrease in cons, which is consistent with the application of decisional balance to other behaviours. In this culture, taste and price considerations are not among the most important in choosing foods, unlike Western cultures

The decisional-balance scale appears to describe this population well. In early stages, it is most beneficial to emphasise the pros, or benefits, of changing. In later stages, reducing cons may be most help-

Application of the TTM to food-based, rather than nutrient-based, goals might allow for more accurate staging of individuals

This is one of the first studies to analyse the relationship between time spent in action and maintenance, weightloss behaviours and weight loss

The TTM appears to accurately describe young adults for fruit and ve etable intak Separate analyses identifie seven clusters that were slightly different for fruit $v$. vegetable consumption
This study supports the application of a staging algorithm to young adults for fruit and vegetable intake. However research with a randomly selected sample is warranted for validation of the algorithm 


\begin{tabular}{|c|c|c|c|c|c|c|}
\hline $\begin{array}{l}\text { Study no. and } \\
\text { reference }\end{array}$ & Research purpose & $\begin{array}{c}\text { Sample } \\
\text { characteristics }\end{array}$ & $\begin{array}{l}\text { Study design } \\
\text { and measures }\end{array}$ & Type of analysis & Findings & Implications \\
\hline $\begin{array}{l}\text { V14 Padula et al. } \\
(2003)^{75} \\
\text { Descriptive study }\end{array}$ & $\begin{array}{l}\text { Use focus groups to } \\
\text { identify key con- } \\
\text { cepts to incorporate } \\
\text { in the development } \\
\text { of instruments to } \\
\text { assess TTM con- } \\
\text { cepts related to fruit } \\
\text { and vegetable } \\
\text { intake }\end{array}$ & $\begin{array}{l}\text { Volunteer sample of } \\
105 \text { adults (aged } 60 \\
\text { years or over; } 87 \% \\
\text { white; average age } \\
75 \text { years; response } \\
\text { rate not given) }\end{array}$ & $\begin{array}{l}\text { Adults were divided into low } \\
\text { and high consumers of } \\
\text { fruits and vegetables. } \\
\text { Separate focus groups } \\
\text { were conducted with } \\
\text { each group. The } 90 \text { min } \\
\text { sessions were tape- } \\
\text { recorded }\end{array}$ & $\begin{array}{l}\text { A series of open-ended } \\
\text { questions, based on } \\
\text { TTM concepts of deci- } \\
\text { sional balance, process } \\
\text { use and self-efficacy, } \\
\text { were developed and } \\
\text { used with the focus } \\
\text { groups. Two indepen- } \\
\text { dent researchers ana- } \\
\text { lysed and interpreted } \\
\text { the data }\end{array}$ & $\begin{array}{l}\text { Pros of eating fruits and veg- } \\
\text { etables that emerged } \\
\text { included: weight control, } \\
\text { better health, taste, nutri- } \\
\text { tional value, reducing con- } \\
\text { stipation and physician } \\
\text { recommendation. Cons } \\
\text { included cost, preparation } \\
\text { difficulty, spoilage and } \\
\text { chewing difficulty. Partici- } \\
\text { pants overwhelmingly } \\
\text { reported preferring written } \\
\text { self-help interventions }\end{array}$ & $\begin{array}{l}\text { This study demonstrated } \\
\text { the effective use of } \\
\text { focus groups for TTM } \\
\text { instrument develop- } \\
\text { ment. Researchers } \\
\text { were able to develop } \\
\text { items for decisional bal- } \\
\text { ance, processes of } \\
\text { change and self-efficacy } \\
\text { that can be tested for } \\
\text { validity }\end{array}$ \\
\hline $\begin{array}{l}\text { V15 Rossi et al. } \\
\quad(2001)^{76} \\
\text { Descriptive study }\end{array}$ & $\begin{array}{l}\text { Validation of two } \\
\text { instruments: deci- } \\
\text { sional balance } \\
\text { questionnaire for } \\
\text { adolescent dietary } \\
\text { fat reduction and the } \\
\text { situational tempta- } \\
\text { tions questionnaire } \\
\text { for adolescents }\end{array}$ & $\begin{array}{l}\text { Volunteer sample of } \\
2639 \text { ninth grade } \\
\text { students from } \\
\text { twelve Rhode Island } \\
\text { high schools (89\% } \\
\text { response rate) }\end{array}$ & $\begin{array}{l}\text { Students completed an } \\
\text { assessment of stage of } \\
\text { change }^{82} \text {, decisional } \\
\text { balance (authors } \\
\text { designed an assess- } \\
\text { ment for this population) } \\
\text { and situational tempta- } \\
\text { tions (authors designed } \\
\text { an assessment for this } \\
\text { population) }\end{array}$ & $\begin{array}{l}\text { Structural equation model- } \\
\text { ling ANOVA and MAN- } \\
\text { OVA were used to } \\
\text { analyse the data }\end{array}$ & $\begin{array}{l}\text { Pros were higher and cons } \\
\text { were lower for subjects in } \\
\text { contemplation and prep- } \\
\text { aration, as compared with } \\
\text { those in precontemplation. } \\
\text { Students in different stages } \\
\text { identified different situa- } \\
\text { tional temptations. This fits } \\
\text { the TTM as predicted }\end{array}$ & $\begin{array}{l}\text { Both measures appeared } \\
\text { to be valid when used } \\
\text { with an adolescent } \\
\text { population }\end{array}$ \\
\hline $\begin{array}{l}\text { V16 Simmons \& } \\
\text { Mesui (1999) }{ }^{77} \\
\text { Descriptive study }\end{array}$ & $\begin{array}{l}\text { Develop a decisional- } \\
\text { balance question- } \\
\text { naire and validate a } \\
\text { readiness to change } \\
\text { questionnaire to } \\
\text { assess dietary fat } \\
\text { reduction, weight } \\
\text { control-related } \\
\text { behaviours and } \\
\text { exercise }\end{array}$ & $\begin{array}{l}\text { First study volunteer } \\
\text { sample of } 105 \text { Paci- } \\
\text { fic islanders of New } \\
\text { Zealand ( } 67 \% \\
\text { female; age } 17-80 \\
\text { years). Second } \\
\text { study sample of } 195 \\
\text { Pacific islanders of } \\
\text { New Zealand (53\% } \\
\text { female; age } 17-70 \\
\text { years). Participation } \\
\text { rates (based on the } \\
\text { size the invited } \\
\text { population) not } \\
\text { specified }\end{array}$ & $\begin{array}{l}\text { The first study sample ( } n \\
\text { 105) completed open- } \\
\text { ended questionnaires } \\
\text { which were used to } \\
\text { develop a closed-ended } \\
\text { decisional-balance } \\
\text { scale. The second study } \\
\text { sample ( } n \text { 195) com- } \\
\text { pleted the decisional- } \\
\text { balance questionnaire } \\
\text { and a previously-devel- } \\
\text { oped readiness to } \\
\text { change questionnaire }\end{array}$ & $\begin{array}{l}\text { Validation of the decisional- } \\
\text { balance scale was con- } \\
\text { ducted using both a } \\
\text { binary and rank order } \\
\text { method. The data from } \\
\text { two randomly selected } \\
\text { subsets of the second } \\
\text { sample were analysed } \\
\text { separately; however, } \\
\text { few differences existed } \\
\text { between the groups }\end{array}$ & $\begin{array}{l}\text { The most frequent pros to } \\
\text { changing each of the three } \\
\text { behaviours were being } \\
\text { healthier, avoiding disease } \\
\text { and being more fit. The most } \\
\text { frequent cons to changing } \\
\text { each behaviour were losing } \\
\text { too much weight, having to } \\
\text { give up favourite high-fat } \\
\text { foods and taking too much } \\
\text { time to exercise. Women } \\
\text { identified more pros than did } \\
\text { men; less educated partici- } \\
\text { pants identified more cons } \\
\text { than did those with college } \\
\text { educations }\end{array}$ & $\begin{array}{l}\text { Pacific island culture is } \\
\text { unique compared with } \\
\text { other cultures worldwide } \\
\text { and diverse among the } \\
\text { subgroups within it, } \\
\text { making validation } \\
\text { research particularly } \\
\text { challenging. Given the } \\
\text { epidemic levels of type } 2 \\
\text { diabetes among Pacific } \\
\text { islanders, the evidence } \\
\text { for the validity of apply- } \\
\text { ing decisional balance } \\
\text { and stage of change for } \\
\text { dietary and exercise } \\
\text { behaviour to this popu- } \\
\text { lation is encouraging }\end{array}$ \\
\hline $\begin{array}{l}\text { V17 Snelling et al. } \\
\text { (2006) } \\
\text { Descriptive study }\end{array}$ & $\begin{array}{l}\text { Develop and validate a } \\
\text { staging algorithm for } \\
\text { Ca intake }\end{array}$ & $\begin{array}{l}\text { Random sample of } 180 \\
\text { male college stu- } \\
\text { dents ( } 92 \% \\
\text { response rate) }\end{array}$ & $\begin{array}{l}\text { Measures included stage of } \\
\text { change }^{105} \text { and a FFQ }\end{array}$ & $\begin{array}{l}\text { One-way ANOVA with post } \\
\text { hoc comparisons were } \\
\text { used to analyse the data }\end{array}$ & $\begin{array}{l}\text { Participants in the pre-action } \\
\text { stages consumed signifi- } \\
\text { cantly less Ca than did those } \\
\text { in action or maintenance. Of } \\
\text { the college males, } 46 \% \\
\text { were assigned to either } \\
\text { action or maintenance with } \\
\text { this algorithm. Self-efficacy } \\
\text { scores increased with stage }\end{array}$ & $\begin{array}{l}\text { The stage-of-change } \\
\text { algorithm appears to } \\
\text { accurately classify male } \\
\text { college students for } \mathrm{Ca} \\
\text { intake }\end{array}$ \\
\hline
\end{tabular}



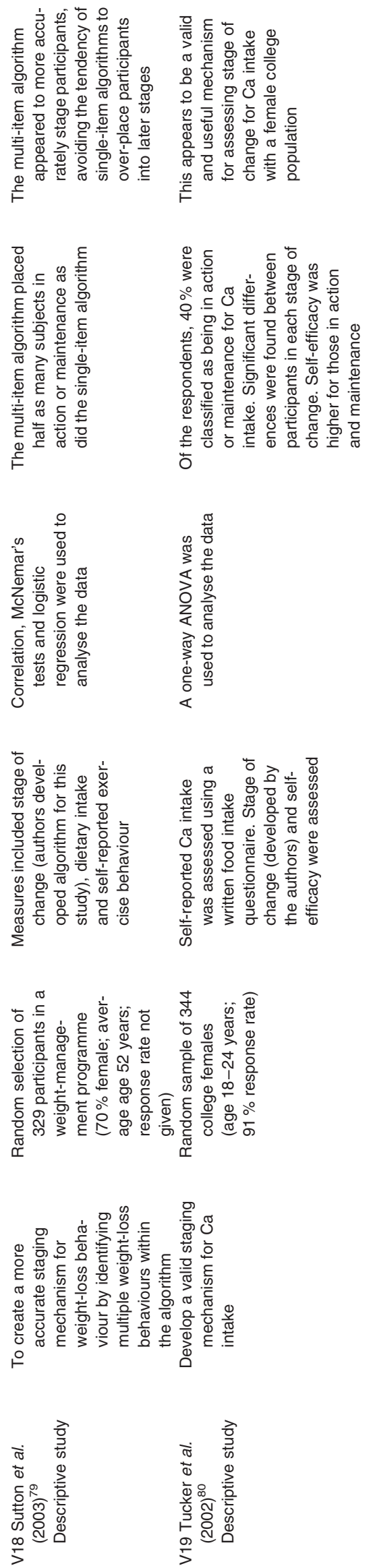

all of the studies using experimental and quasi-experimental designs.

\section{Validation studies}

Of the nineteen validation studies summarised in Table 3, thirteen focused on the development and/or validation of a stage-of-change algorithm. These included one for each of the following behaviours or situations: fruit and vegetable intake (study number V8), dietary fat reduction (study numbers V5 and V16), readiness for recovery from anorexia nervosa (study number V6) and weight-loss behaviours (study numbers V16 and V18). In two studies, an algorithm was created for Ca intake (study numbers V17 and V19). Six studies included the development and testing of other TTM measures with specific populations. In four of these studies, decisional-balance measures for fruit and vegetable intake were created for Chinese adults (study number V9), senior citizens (study number V14), low-income African-American adolescents (study number V4) and middle-class adolescents (study number V15). One study featured the development of a decisional-balance scale to assess fruit and vegetable intake for culturally diverse male college students (study number V1). A second study featured the development of a decisional-balance scale to assess dietary fat reduction and other weight-loss behaviours among Pacific islanders (study number V16). Padula et al. ${ }^{75}$ (study number V14) also tested the application of self-efficacy to fruit and vegetable intake with a senior citizen population. Di Noia et $a .^{65}$ (study number V4) developed both a processes-ofchange scale and a self-efficacy assessment tool for lowincome African-American adolescents to assess fruit and vegetable intake. Rossi et al. $^{76}$ (study number V15) also tested an instrument to measure situational temptations with the fruit and vegetable intake of adolescents.

Of the nineteen studies, only three used a prospective design and were designated as 'multiple time series' in Table 3. Eight studies randomly selected participants and eleven used convenience sampling methods. The populations of these studies varied widely, and included Dutch adults, British adults, Pacific islanders, Finnish diabetic patients, young adults, senior citizens, overweight females, African-American females, low-income African-American adolescents, middle-class adolescents, females with anorexia nervosa, female college students and culturally diverse male college students.

Of the three categories of studies in the present review (validation, population and intervention), the category studied in greatest depth in the Horwath ${ }^{4}$ review was the group of validation studies. In her analysis of twenty-five studies attempting to validate one or more constructs of the TTM as related to dietary behaviour, Horwath ${ }^{4}$ drew several important conclusions. The first was that it is much more complicated to stage individuals for dietary behaviour than for smoking behaviour. Many of the staging algorithms in her review tended to place individuals in action or maintenance, when in reality they were not yet in action for a specific nutrition behaviour. Another staging concern among staging nutrition behaviour is that some behaviours, such as consuming $30 \%$ or less energy from fat, are harder for consumers to measure than others, such as eating five 
servings of fruit or vegetables per d. Horwath ${ }^{4}$ suggested that future studies needed to offer simpler and more specific goals that consumers can easily assess within a short time frame. In the present review, two studies successfully addressed the issue of inaccurately identifying pre-action participants as being in action or maintenance through the development of new staging algorithms for fruit and vegetable intake (study number V8) and for multiple weight-loss behaviours (study number V18). No studies specifically attempted to identify dietary behaviours that were easy for participants to measure, and the most common behaviours measured were fruit and vegetable consumption and the reduction of dietary fat.

The second important finding of Horwath ${ }^{4}$ was that the processes of change for dietary behaviour were minimally studied and validated, except for a few studies related to dietary fat reduction. In the present review, two studies (numbers V4 and V14) included the development of a tool to assess the use of the processes of change for fruit and vegetable consumption among low-income African-American middle-school students and diverse, male college students.

Horwath $^{4}$ identified a stronger body of studies linking self-efficacy with dietary behaviour, most notably dietary fat reduction and increases in fruit and vegetable consumption. As expected, individuals in pre-action stages had lower selfefficacy scores than did those in action and maintenance. One study in the present review included the application of self-efficacy to senior citizens for fruit and vegetable consumption (study number V14), although the authors did not specify how it applied to the study findings. Di Noia et $a l .{ }^{65}$ (study number V4) created a process-of-change scale for low-income African-American middle-school students and found that those in action or maintenance were more likely than their peers in pre-action stages to report using a greater number of the processes, although they did not report using the behavioural processes more frequently than the cognitive ones. (The TTM postulates that individuals are more likely to use the cognitive processes in pre-action stages and the behavioural processes in action and maintenance.)

Decisional balance also appeared to relate predictably with stage of change for dietary fat reduction, fruit and vegetable intake and increased consumption of milk products $^{4}$, although two of the seven studies cited in Horwath's review were of unpublished results. Four studies in the present review included the development of a decisional balance instrument for a specific population. Ling $\&$ Horwath $^{70}$ (study number V9) found that a culturally specific decisional-balance scale to assess fruit and vegetable consumption among Chinese adults followed the same pattern as it does for other populations, with pros increasing in contemplation and cons decreasing in preparation, action and maintenance. A focus group method was used to identify pros and cons of fruit and vegetable consumption among senior citizens (study number V14). Di Noia et al. $^{65}$ (study number V4) found that decisional balance applied in predicted ways to a low-income AfricanAmerican middle-school sample, with pros rated higher than the cons by the action stage. Simmons \& Mesui ${ }^{77}$ (study number V16) found that Pacific islanders identified pros and cons that were culturally specific, yet also found support for the use of the decisional-balance construct with this population. Finally, a decisional-balance questionnaire was successfully developed to assess fruit and vegetable consumption among ninth-graders (study number V15).

\section{Conclusions}

In this section of the review, we answer the three research questions on which the present review is based. We also evaluate the evidence for using stage-matched dietary behaviour interventions, using the criteria presented earlier in the paper. We begin by answering the three research questions in order.

How has the transtheoretical model been used to describe the dietary behaviours and nutrition goals of populations?

Have researchers been able to accurately classify participants according to stage for various dietary behaviours and nutritional goals?

In the body of literature reviewed, the TTM has been applied mainly to describe fruit and vegetable intake or dietary fat intake, with very few studies focusing on other food groups or nutrients. Researchers have been able to classify participants accurately, and this success has been most consistently related to use of FFQ. Success in staging based on other food groups was demonstrated, but studies are too few to be able to identify scientific consensus. Inconsistency in staging occurred mainly when the focus was on nutrient intake rather than food intake, similar to what has been noted by Horwath ${ }^{4}$.

What is the evidence for using stage-based interventions with populations to achieve positive nutritional goals and behaviours?

Using the criteria established by Anderson \& O'Donnell ${ }^{15}$, we rated the evidence as indicative for dietary fat reduction and suggestive for other dietary behaviours. While there are a growing number of studies supporting the use of stagematched interventions for fruit and vegetable consumption, there are few, if any, studies which provide evidence for stage-matched interventions for other dietary behaviours. While nineteen studies supported the use of stage-matched interventions, two did not. These two studies both utilised non-white, low-income populations, suggesting that the interventions themselves and the algorithms used to assess stage of change may not apply equally to all socio-economic and cultural groups. Of the nineteen interventions using experimental or quasi-experimental designs, all were well designed with one or no threats to internal validity, adding to the evidence for the use of stage-matched interventions for dietary fat reduction and fruit and vegetable consumption.

In a recent review of thirty-seven TTM-based interventions employing a randomised control trial design ${ }^{83}$, the authors raised several important concerns with the quality of these studies and the inferences which can and should be drawn from them. This review, which included trials of interventions for dietary behaviour, smoking cessation, exercise, screening mammography, mental health treatment, 
tobacco or alcohol prevention, and multiple lifestyle changes, demonstrated a lack of evidence for TTM-based interventions. One of the critical issues raised was the potential for poorly designed TTM-based interventions due to limited application of the model in assessing participants and creating interventions for them. Bridle et al. ${ }^{83}$ found that, in many cases, interventions were vaguely described and staging mechanisms lacked evidence for validity. They attributed this to a limitation of the TTM itself in clearly discerning discrete stages and specifically identifying the processes of change that should be used in each stage. They also pointed out that, in many of these studies, the intensity of the TTM-based intervention was potentially greater than that of the comparison intervention, which could explain its apparent effectiveness in these studies. One potential limitation of drawing inferences from the Bridle et al. ${ }^{83}$ review specific to dietary behaviour is that only five dietrelated interventions met the review criteria and were included. These included three published articles in peerreviewed journals, one doctoral dissertation and one conference proceedings abstract.

In the present review, we found some improvement among the intervention studies in two of the three problem areas identified by Bridle et al. ${ }^{83}$. In our judgment, ten of the nineteen experimental or quasi-experimental intervention studies provided sufficient detail about the interventions to allow other practitioners to replicate them. Four studies utilised the 'expert systems' approach ${ }^{46,47,50,51}$. Two studies used the Patient-Centered Assessment and Counseling for Exercise plus Nutrition ${ }^{40,52}$. Auslander et al. $^{38}$ clearly referenced the Eat Well, Live Well programme, Clark et al. ${ }^{41}$ clearly cited the sources of the assessments used in patient counselling and Steptoe et al. ${ }^{58}$ provided references for the Changes of Heart Program. In each of these studies, the authors specified the name of the intervention and referred to another source in which the intervention was described in detail. In addition, Resnikow et al. ${ }^{53}$ both described within the article and referenced the Motivational Interviewing techniques used in this intervention. Of this same group of nineteen experimental or quasi-experimental intervention studies, only four included assessments of TTM measures other than stage of change. Prochaska et al. ${ }^{50,51}$ also assessed processes of change and decisional balance in two studies. Finckenor et al. ${ }^{43}$ used the processes of change to created stage-matched interventions for college students. Johnson et $a l^{46}$ also assessed processes of change and decisional balance in their expert system intervention for patients using cholesterol-lowering medications. While selfefficacy was measured in several other interventions, the additional presence of this measure alone was not considered evidence of using multiple TTM constructs, given that many behaviour-change theories incorporate selfefficacy. Finally, we fully concur with Bridle et al. ${ }^{83}$ on the lack of intensity of interventions provided to participants in control or comparison groups. Almost all of the intervention studies in this review compared a stage-matched intervention to 'usual care' or to no intervention at all. It is no surprise that a TTM-based intervention would yield significantly better results than no intervention at all; this would be true for most interventions based on many of the existing health-behaviour theories. The more important question is whether a TTM-based intervention is more effective than other types of interventions, particularly if other interventions require fewer resources to implement. We recommend that future research compare multiple interventions to determine which are the most effective and efficient.

It would be useful to see future research compare stagematched to stage-mismatched dietary interventions. These types of studies have been conducted for tobacco ${ }^{84-88}$ and physical activity ${ }^{89,90}$. It is important to note that these seven interventions varied in methodology and overall quality of design, yet all but one of the studies raise doubts as to the superiority of the stage-matched intervention over the stagemismatched intervention.

Do valid and reliable measures exist to describe the nutritional status and behaviours of populations using the transtheoretical model constructs? Do they still only exist for stage of change, or have measures been developed for processes of change, situational temptation, decisional balance and self-efficacy?

Progress has clearly been made in developing valid and reliable stage-of-change algorithms for dietary behaviour, although more validation research is needed. Since the Horwath review in $1999^{4}$, the bulk of published validation literature has focused on the development of stage-ofchange algorithms for specific populations. This is an important step forward, since staging algorithms appear to be culturally and demographically specific. Few researchers have sought to refine and improve existing algorithms to correct for the problem of placing pre-action individuals into action and maintenance, although more have developed algorithms for dietary behaviours that are easier for the average consumer to measure. It is encouraging that four published studies since the Horwath review have attempted to develop and validate measures for decisional balance, processes of change, situational temptations, and selfefficacy, but more studies on these constructs are needed.

Based on this body of literature, it was apparent that there is little consensus on the best algorithm to use for each dietary behaviour, although the existence of multiple validated algorithms add to the validity of the stage-ofchange construct. Twenty-four different staging algorithms were used in these studies (including the eighteen identified among the population studies) and another four studies employed staging algorithms that were not identified at all (noted as 'unspecified' in Tables 1,2 and 3). We estimate that approximately fifteen of these algorithms have been tested for validity and reliability, although it is difficult to discern this in a few studies. Some studies used algorithms that are specific to one behaviour, such as fruit and vegetable consumption or dietary fat reduction, while others used a form of the algorithm that was initially developed for smoking and simply adapted it for a nutrition behaviour or status. The most frequently used algorithms were for fruit and vegetable consumption ${ }^{81}$, dietary fat reduction ${ }^{82}$, and an adapted form of the algorithm created for smoking behaviour ${ }^{3}$.

The findings of the present review are limited in that we used a subjective method to categorise and evaluate each 
study individually, as well as evaluate the body of literature as a whole. While we strove to use a systematic approach and clear criteria for the assessment of this literature, it remains a qualitative process that relies upon human judgment. While we tried to include all of the relevant literature, it is also possible that an appropriate study was inadvertently omitted from the present review.

We make the following recommendations for future research in the application of the TTM to dietary behaviour:

(1) The use of previously tested and validated forms of a staging algorithm is desirable when possible, as well as the clear identification of the staging algorithm used. Correctly staging individuals is the cornerstone of all TTM applications. It would enhance the validity of the application of the TTM to dietary behaviour if consensus could be reached for the staging algorithm used with each dietary behaviour. This would be particularly useful for fruit and vegetable consumption and dietary fat reduction, as they appear to be the most often-studied behaviours.

(2) The application of the entire TTM is important in designing and evaluating interventions, rather than just the stage-of-change construct. For example, it would be very useful to know which processes of change facilitate forward stage movement for each dietary behaviour, and how these vary between populations. Similarly, understanding how decisional balance, situational temptations and self-efficacy affect stage progression would also be useful in designing effective interventions.

(3) More experimental studies are needed to determine if TTM-based dietary interventions are more effective than other kinds of interventions. The current evidence suggests that they are effective for dietary fat reduction and may be for fruit and vegetable consumption, but a larger body of evidence is needed to state this conclusively. Experimental studies are completely lacking for TTM-based interventions related to other dietary behaviours, and these are also warranted.

The progress that has been made in the body of research on the application of the TTM to dietary behaviour is encouraging. Several of Horwath's ${ }^{4}$ concerns and recommendations for future research have been addressed; however, more research is needed to determine with confidence if employing the TTM to describe dietary behaviour and plan dietary interventions is the most effective way to promote healthier dietary intake for many populations.

\section{Acknowledgements}

We wish to thank John Glover, Pharm. D \& Pfizer, Inc. for assisting with the database search in EMBASE.

\section{References}

1 Prochaska JO \& DiClemente CC (1982) Transtheoretical therapy: toward a more integrative model of change. Psychother Theory Res Pract 2, 176-288.
2 Prochaska JO, Velicer WF, Rossi JS et al. (1994) Stages of change and decisional balance for 12 problem behaviors. Health Psychol 13, 39-46.

3 DiClemente CC, Prochaska JO, Fairhurst SK, Velicer WF, Velasquez MM \& Rossi JS (1991) The process of smoking cessation: an analysis of precontemplation, contemplation, and preparation stages of change. J Consult Clin Psychol 59, 295-304.

4 Horwath CC (1999) Applying the transtheoretical model to eating behavior change: challenges and opportunities. Nutr Res Rev 12, 281-317.

5 Prochaska JO, DiClemente CC \& Norcross JC (1992) In search of how people change: applications to addictive behaviors. Am Psychol 47, 1102-1114.

6 Janis IL \& Mann L (1977) Decision Making: A Psychological Analysis of Conflict, Choice and Commitment. New York: Free Press.

7 Bandura A (1977) Self-efficacy: toward a unifying theory of behavioral change. Psychol Rev 84, 191-215.

8 DiClemente CC (1981) Self-efficacy and smoking cessation maintenance: a preliminary report. Cognit Ther Res 5, $175-187$.

9 Velicer WF, DiClemente CC, Rossi JS \& Prochaska JO (1990) Relapse situations and self-efficacy: an integrated model. Addict Behav 15, 271-283.

10 Spencer L, Pagell F, Hallion ME \& Adams TB (2002) Applying the transtheoretical model of tobacco cessation and prevention: a review of literature. Am J Health Promot 17, 7-71.

11 Spencer L, Adams T, Malone S, Roy L \& Yost E (2006) Applying the transtheoretical model to exercise: a systematic and comprehensive review of literature. Health Promot Pract 7, 428-443.

12 Spencer L, Pagell F \& Adams T (2004) Applying the transtheoretical model to cancer screening behavior: a review of literature. Am J Health Behav 29, 36-56.

13 Migneault JP, Adams TB \& Read JP (2005) Application of the transtheoretical model to substance abuse: historical development and future directions. Drug Alcohol Rev 24, 437-448.

14 Harris RP, Helfand M, Woolf SH, Lohr K, Mulrow CD, Teutsch SM \& Atkins D (2001) Current methods of the U.S. Preventive Task Force: a review of the process. Am J Prev Med 20, 21-35.

15 Anderson DR \& O'Donnell MP (1994) Toward a health promotion research agenda: "State of the Science" reviews. Am J Health Promot 8, 462-465.

16 Burke V, Richards J, Milligan RAK, Beilin LJ, Dunbar D \& Gracey MP (2000) Stages of change for health-related behaviours in 18 year-old Australians. Psychol Health 14, 1061-1075.

17 Campbell MK, Tessaro I, DeVellis B, Benedict S, Kelsey K, Belton L \& Henriquez-Roldan C (2000) Tailoring and targeting a worksite health promotion program to address multiple health behaviors among blue-collar women. Am J Health Promot 14, 306-313.

18 Clark PG, Rossi JS, Greaney ML, Riebe DA, Greene GW, Saunders SD, Lees FD \& Nigg CR (2005) Intervening on exercise and nutrition in older adults. J Aging Health 17, $753-778$.

19 Chung SJ, Hoerr S, Levine R \& Coleman G (2006) Processes underlying young women's decisions to eat fruits and vegetables. J Hum Nutr Diet 19, 287-298.

20 Frame CJ, Green CG, Herr DG, Myers JE \& Taylor ML (2001) The stages of change for dietary fat and fruit and vegetable intake of patients at the outset of a cardiac rehabilitation program. Am J Health Promot 15, 405-413. 
21 Frenn M, Malin S, Villarruel AM, Slaikeu K, McCarthy S, Freema J \& Nee E (2005) Determinants of physical activity and low fat diet among low income African American and Hispanic middle school students. Public Health Nurs 22, 89-97.

22 Frenn M \& Malin S (2003) Diet and exercise in low-income culturally diverse middle school students. Public Health Nurs 20, 361-368.

23 Greene GW, Fey-Yensan N, Padula C, Rossi S, Rossi JS \& Clark PG (2004) Difference in psychosocial variables by stage of change in fruit and vegetables in older adults. $J \mathrm{Am}$ Diet Assoc 104, 1236-1243.

24 Gulliver P \& Horwath CC (2001) Assessing women's perceived benefits, barriers, and stage of change for meeting milk product consumption recommendations. J Am Diet Assoc 101, 1354-1357.

25 Gulliver P \& Horwath CC (2001) Women's readiness to follow milk product consumption recommendations: design and evaluation of a stage of change algorithm. J Hum Nutr Diet 14, 277-286.

26 Hawkins DS, Hornsby PP \& Schorling JB (2001) Stages of change and weight loss among rural African American women. Obes Res 9, 5-67.

27 Lea EJ, Crawford D \& Worsley A (2006) Consumers' readiness to eat a plant-based diet. Eur J Clin Nutr 60, $342-351$.

28 Logue EE, Sutton K, Jarjoura D \& Smucker W (2000) Obesity management in primary care: assessment of readiness to change among 284 family practice patients. $J$ Am Board Fam Med 13, 164-171.

29 Lopez-Azpiazu I, Martinez-Gonzalez MA, Leon-Mateos A, Gibney M \& Martinez JA (2000) Stages of dietary change and nutrition attitudes in the Spanish population. Public Health 114, 183-189.

30 Nothwehr F, Snetselaar L, Yang J \& Wu H (2006) Stage of change for healthful eating and use of behavioral strategies. $J$ Am Diet Assoc 106, 1035-1041.

31 O'Hea EL, Wood KB \& Brantley PJ (2003) The transtheoretical model: gender differences across 3 health behaviors. Am J Health Behav 27, 645-656.

32 Pullen C \& Walker SN (2002) Midlife and older rural women's adherence to U.S. dietary guidelines across stages of change in healthy eating. Public Health Nurs 19, $170-178$.

33 Tassell N \& Flett R (2005) Stages of change for fruit and vegetable intake and dietary fat modification in Maori women: some relationships with body attitudes and eating behaviors. N Z J Psychol 34, 28-34.

34 Vallis M, Ruggiero L, Greene G, Jones H, Zinman B, Rossi S, Edwards L, Rossi JS \& Prochaska JO (2003) Stages of change for healthy eating in diabetes. Diabetes Care 26, $1468-1474$.

35 Van Duyn MAS, Kristal AR, Dodd K, Campbell MK, Subar AF, Stables G, Nebeline L \& Glanz K (2001) Association of awareness, intrapersonal and interpersonal factors, and stage of dietary change with fruit and vegetable consumption: a national survey. Am J Health Promot 16, 69-78.

36 Wee CC, Davis RB \& Phillips RS (2004) Stage of readiness to control weight and adopt weight control behaviors in primary care. J Gen Intern Med 20, 410-415.

37 Armitage CJ (2006) Evidence that implementation intentions promote transitions between the stages of change. $J$ Consult Clin Psychol 74, 141-151.

38 Auslander W, Haire-Joshu D, Houston C, Rhee C \& Williams JH (2002) A controlled evaluation of staging dietary patterns to reduce the risk of diabetes in African American women. Diabetes Care 25, 809-814.

39 Bradbury J, Thomason JM, Jepson NJ, Walls AW, Allen PF \& Moynihan PJ (2006) Nutrition counselling increases fruit and vegetable intake in the endentulous. $J$ Dent Res 85, 463-468.

40 Calfas KJ, Sallis JF, Zabinski MF, Wilfley DE, Rupp J, Prochaska JJ, Thompson S, Pratt M \& Patrick K (2002) Preliminary evaluation of a multi-component program for nutrition and physical activity change in primary care: PACE + for adults. Prev Med 34, 153-162.

41 Clark M, Hampson SE, Avery L \& Simpson R (2004) Effects of a brief tailored intervention on the process and predictors of lifestyle behaviour change in patients with type 2 diabetes. Psychol Health Med 9, 440-449.

42 Cookson S, Heath A \& Bertrand L (2000) The HeartSmart Family Fun Pack: an evaluation of family-based intervention for cardiovascular risk reduction in children. Can J Public Health 91, 256-259.

43 Finckenor M \& Byrd-Bredbenner C (2000) Nutrition intervention group program based on preaction-stage oriented change processes of the transtheoretical model promotes long-term reduction in dietary fat intake. J Am Diet Assoc 100, 335-342.

44 Frenn M, Malin S \& Bansal NK (2003) Stage-based interventions for low-fat diet with middle school students. $J$ Pediatr Nurs 18, 36-45.

45 Greene GW, Riebe D, Ruggiero L, Caldwell M \& Blissmer B (2003) A pilot home-based, healthy lifestyle weight management program. Top Clin Nutr 18, 136-142.

46 Johnson SS, Driskell MM, Johnson JL, Dyment SJ, Prochaska JO, Prochaska JM \& Bourne L (2006) Transtheoretical model intervention for adherence to lipidlowering drugs. Dis Manag 9, 102-114.

47 Jones H, Edwards L, Vallis MT, Ruggiero L, Rossi SR, Rossi JS, Greene G, Prochaska JO \& Zinman B (2003) Diabetes Stages of Change (DiSC) study. Changes in diabetes selfcare behaviors make a difference in glycemic control. Diabetes Care 26, 732-737.

48 Keller S, Donner-Banzhoff N, Kaluza G, Baum E \& HeinzDieter B (2000) Improving physician-delivered counseling in a primary care setting: lessons from a failed attempt. Educ Health 13, 387-397.

49 Mau MK, Curb JD, Glanz K, Severino R, Grove JS \& Johnson B (2001) Mediators of lifestyle behavior change in native Hawaiians. Diabetes Care 24, 1770-1776.

50 Prochaska JO, Velicer WF, Redding C et al. (2005) Stagebased expert systems to guide a population of primary care patients to quit smoking, eat healthier, prevent skin cancer, and receive regular mammograms. Prev Med 41, 406-416.

51 Prochaska JO, Velicer WF, Rossi JS, Redding CA, Greene GW, Rossi SR, Sun X, Fava JL, Laforge R \& Plummer BA (2004) Multiple risk expert systems interventions: impact of simultaneous stage-matched expert system interventions for smoking, high-fat diet, and sun exposure in a population of parents. Health Psychol 23, 503-516.

52 Proper KI, van der Beek AJ, Hildebrandt VH, Twisk JWR \& van Mechelen W (2003) Short term effect of feedback on fitness and health measurements on self reported appraisal of the stage of change. Br J Sports Med 37, 529-534.

53 Resnicow K, McCarty F \& Baranowski T (2003) Are precontemplators less likely to change their dietary behavior? A prospective analysis. Health Educ Res 18, 693-705.

54 Riebe D, Blissmer B, Greene G, Caldwell M, Ruggiero L, Stillwell KM \& Nigg CR (2005) Long-term maintenance of exercise and healthy eating behaviors in overweight adults. Prev Med 40, 769-778. 
55 Riebe D, Greene GW, Ruggiero L, Stillwell KM, Blissmer B, Nigg CR \& Caldwell M (2003) Evalulation of a healthylifestyle approach to weight management. Prev Med 36, 45-54.

56 Soweid RAA, Kak FE, Major SC, Karam DK \& Rouhana A (2003) Changes in health-related attitude and self-reported behaviour of undergraduate students at the American University of Beirut following a health awareness course. Educ Health 16, 265-278.

57 Steptoe A, Perkins-Porras L, McKay C, Rink E, Hilton S \& Cappuccio FP (2003) Behavioural counselling to increase consumption of fruit and vegetables in low income adults: randomized trial. BMJ 326, 855-859.

58 Steptoe A, Kerry S, Rink E \& Hilton S (2001) The impact of behavioral counseling on stage of change in fat intake, physical activity, and cigarette smoking in adults at increased risk of coronary heart disease. Am J Public Health 91, 265-269.

59 Taylor T, Serrano E, Anderson J \& Kendall P (2000) Knowledge, skills, and behavior improvements on peer educators and low-income Hispanic participants after a stage of change-based bilingual nutrition education program. $J$ Community Health 25, 241-262.

60 van der Veen J, Bakx C, van den Hoogen H, Verheijden M, van den Bosch W, van Weel C \& van Staveren W (2002) Stage-matched nutrition guidance for patients at elevated risk for cardiovascular disease: a randomized intervention study in family practice. J Fam Pract 51, 751-758.

61 Verheijden MW, Van derVeen JE, Bakx JC, Akkermans RP, Van den Hoogen HJM, Van Staveren WA \& Van Weel C (2004) Stage-matched nutrition guidance: stages of change and fat consumption in Dutch patients at elevated cardiovascular risk. J Nutr Educ Behav 36, 228-237.

62 De Oliveira MDCF, Anderson J, Auld G \& Kendall P (2005) Validation of a tool to measure processes of change for fruit and vegetable consumption among male college students. $J$ Nutr Educ Behav 37, 2-11.

63 de Vet E, de Nooijer J, de Vries NK \& Brug J (2005) Determinants of forward stage transition from precontemplation and contemplation for fruit consumption. Am J Health Promot 19, 278-285.

64 de Vet E, de Nooijer J, de Vries NK \& Brug J (2005) Stages of change for fruit intake: a longitudinal examination of stability, stage transitions and transition profiles. Psychol Health 20, 415-428.

65 Di Noia J, Schinke SP, Prochaska JO \& Contento IR (2006) Application of the transtheoretical model to fruit and vegetable consumption among economically disadvantaged African-American adolescents: preliminary findings. Am J Health Promot 20, 342-348.

66 Hargreaves MK, Schlundt DG, Buchowski MS, Hardy RE, Rossi SR \& Rossi JS (1999) Stage of change and the intake of dietary fat in African-American women: improving stage assignment using the eating styles questionnaire. J Am Diet Assoc 99, 1392-1399.

67 Jordan PJ, Redding CA, Troop NA, Treasure J \& Serpell L (2003) Developing a stage of change measure for assessing recovery from anorexia nervosa. Eat Behav 3, 365-385.

68 Kasila K, Poskiparta M, Karhila P \& Kettunen T (2003) Patients' readiness for dietary change at the beginning of counseling: a transtheoretical model-based assessment. $J$ Hum Nutr Diet 16, 159-166.

69 Lamb R \& Joshi MS (2004) Active but not consistent: dietary behaviour and the stages of change model. Psychol Health 19, 543-559.

70 Ling AM \& Horwath CC (2001) Perceived benefits and barriers of increased fruit and vegetable consumption: validation of a decisional balance scale. J Nutr Educ 33, 257-265.

71 Ling AM \& Horwath CC (2000) Defining and measuring stages of change for dietary behaviors: readiness to meet fruit, vegetable, and grain guidelines among Chinese Singaporeans. J Am Diet Assoc 100, 898-904.

72 Logue EE, Jarjoura DG, Sutton KS, Smucker WD, Baughman KR \& Capers CF (2004) Longitudinal relationships between elapsed time in the action stages of change and weight loss. Obes Res 12, 1499-1508.

73 Ma J, Betts NM, Horacek T, Georgiou C, White A \& Nitzke $S$ (2002) The importance of decisional balance and selfefficacy in relation to stages of change for fruit and vegetable intake by young adults. Am J Health Promot 16, 157-166.

74 Ma J, Betts NM \& Horacek T (2001) Measuring stage of change for assessing readiness to increase fruit and vegetable intake among 18 to 24 year olds. Am J Health Promot 16, 88-97.

75 Padula CA, Rossi S, Nigg C, Lees F, Fey-Yensan N, Greene G \& Clark P (2003) Using focus groups for instrument development: application of the transtheoretical model to fruit and vegetable behaviors of older adults. $J$ Nutr Elder 22, 13-33.

76 Rossi SR, Greene GW, Rossi JS, Plummer BA, Benisovich SV, Keller S, Velicer WF, Redding CA, Prochaska JO, Pallonen UE \& Meier KS (2001) Validation of decisional balance and situational temptations measures for dietary fat reduction in a large school-based population of adolescents. Eating Behav 2, 1-18.

77 Simmons D \& Mesui J (1999) Decisional balance and stage of change in relation to weight loss, exercise and dietary fat reduction among Pacific Islands people. Asia Pac J Clin Nutr 8, 39-45.

78 Snelling S, Adams T, Korba C \& Tucker L (2006) Stages of change algorithm for calcium intake by male college students. J Am Diet Assoc 106, 904-907.

79 Sutton K, Logue E, Jarjoura D, Baughman K, Smucker W \& Capers C (2003) Assessing dietary and exercise stage of change to optimize weight loss interventions. Obes Res 11, 641-652.

80 Tucker LJ, Snelling AM \& Adams TB (2002) Development and validation of a stages of change algorithm for calcium intake for college female students. J Am Coll Nutr 21, 530-535.

81 Laforge RG, Greene GW \& Prochaska JO (1994) Psychosocial factors influencing low fruit and vegetable consumption. J Behav Med 17, 361-374.

82 Greene GW \& Rossi SR (1998) Stages of change for reducing dietary fat intake over 18 months. $J$ Am Diet Assoc 98, 529-534.

83 Bridle C, Riemsma RP, Pattenden J, Sowden AJ, Mather L, Watt IS \& Walker A (2005) Systematic review of the effectiveness of health behavior interventions based on the transtheoretical model. Psychol Health 20, 283-301.

84 Quinlan KB \& McCaul KD (2000) Matched and mismatched interventions with young adult smokers: testing a stage theory. Health Psychol 19, 165-171.

85 Segan CJ, Borland R \& Greenwood KM (2002) Do transtheoretical model measures predict the transition from preparation to action in smoking cessation? Psychol Health 17, 417-435.

86 Dijkstra A, Tromp D \& Conijn B (2003) Stage-specfic psychological determinants of stage transition. Br J Health Psychol 8, 423-437.

87 Aveyard P, Lawrence T, Cheng KK, Griffin C, Croghan E \& Johnson C (2006) A randomized controlled trial of smoking cessation for pregnant women to test the effect of a transtheoretical model-based intervention on movement in 
stage and interaction with baseline stage. $\mathrm{Br} J$ Health Psychol 11, 263-278.

88 Dijkstra A, Conijn B \& De Vries H (2006) A matchmismatch test of a stage model of behaviour change in tobacco smoking. Addiction 101, 1035-1043.

89 Blissmer B \& McAuley E (2002) Testing the requirements of stages of physical activity among adults: the comparative effectiveness of stage-matched, mismatched, standard care, and control interventions. Ann Behav Med 24, 181-189.

90 Laplante MC (2004) The effects of stage-matched, stage-mismatched, and standard care interventions on physical activity behavior, stage transition, and hypothesized mediators of change: test of a stage model. In Dissertation Abstracts International: Section B: The Sciences and Engineering 64(10-B), pp. 5222, http://www.socialsciences. uottawa.ca/psy/eng/thesisdetails.asp? ID $=593$.

91 Glanz K, Patterson RE, Kristal AR, DiCelmente CC, Heimendinger J, Linnan L \& McLerran D (1994) Stages of change in adopting healthy diets: fat, fibre and correlates of nutrient intake. Health Educ Q 21, 499-519.

92 Reed GR, Velicer WF, Prochaska JO, Rossi JS \& Marcus BH (1997) What makes a good staging algorithm: examples from regular exercise. Am J Health Promot 12, 57-66.

93 Brug J, Glanz K \& Kok G (1997) The relationship between self-efficacy, attitudes, intake compared to others, consumption, and stages of change related to fruit and vegetables. Am J Health Promot 12, 25-30.

94 Chung SJ (2001) Validity and reliability of stage of change instruments and processes of change to eat fruit and vegetables. Disseration. East Lansing, MI: Michigan State University.

95 Povey R, Conner M, Sparkes P, James R \& Shepherd R (1999) A critical examination of the application of the transtheoretical model's stages of change to dietary behaviors. Health Educ Res 14, 641-651.

96 Van Duyn MA, Heimendinger J, Russek-Cohen E, DiClemente CC, Sims LS, Subar AF, Krebs-Smith SM, Pivonka E \& Kahle LL (1998) Use of transtheoretical model of change to successfully predict fruit and vegetable consumption. J Nutr Educ 30, 371-380.

97 Haire-Joshu D, Auslander WF, Houston C \& Williams JH (1999) Staging of dietary patterns among African-American women. Health Educ Behav 26, 90-102.

98 Lechner J, Brug J, de Vries H, van Assema P \& Mudde A (1998) Stages of change for fruit, vegetable and fat intake: consequences of misconception. Health Educ Res 13, 1-11.

99 Lamb R \& Joshi S (1996) The stage model and processes of change in dietary fat reduction. J Hum Nutr Diet 9, 43-53.

100 Kristal AR, Curry SJ, Shattuck AL, Feng Z \& Li S (2000) A randomized trial of a tailored, self-help dietary intervention: the Puget sound eating patterns study. Prev Med 31, 380-389.

101 Basler HD, Jakle C, Keller S \& Baum D (1999) Selbstwirksamkeit, entscheidungsbalance und die motivation zu sportlicher aktivität: eine unter-suchung zum transtheoretischen modell der verhaltensänderung (Self effectiveness, decision balance and the motivation to sporting activity: an investigation for the transtheoretical model of the behaviour change). Z Diff Diagn Psychol 20, 203-216.

102 Greene GW, Rossi SR, Reed GR, Wiley C \& Prochaska JO (1994) Stages of change for reducing dietary fat to $30 \%$ of energy or less. J Am Diet Assoc 94, 1105-1110.

103 Netherlands Nutrition Center (1993) The 1992 Dutch National Food Consumption Survey (in Dutch). The Hague, The Netherlands: Netherlands Nutrition Center.

104 Curry SJ, Kristal AR \& Bowen D (1992) An application of the stage model of behaviour change to dietary fat reduction. Health Educ Res 7, 494-503.

105 Campbell MK, Symons M, Demar-Wahnefried W, Pollamus B, Bernhardt JM, McClelland JW \& Washington C (1998) Stages of change and psychosocial correlates of fruit and vegetable consumption among rural African American church members. Am J Health Promot 12, $185-191$.

106 Laforge RG, Velicer WF, Richmond RL \& Owen N (1999) Stage distributions for five health behaviors in the United States and Australia. Prev Med 28, 61-74. 